Portland State University

PDXScholar

$12-15-1971$

\title{
A regional approach: city-county consolidation as a method of local governmental reorganization
}

Anthony Gene White

Portland State University

Follow this and additional works at: https://pdxscholar.library.pdx.edu/open_access_etds

Part of the American Politics Commons, Models and Methods Commons, and the Public Affairs, Public Policy and Public Administration Commons

Let us know how access to this document benefits you.

\section{Recommended Citation}

White, Anthony Gene, "A regional approach: city-county consolidation as a method of local governmental reorganization" (1971). Dissertations and Theses. Paper 1592.

https://doi.org/10.15760/etd.1592

This Thesis is brought to you for free and open access. It has been accepted for inclusion in Dissertations and Theses by an authorized administrator of PDXScholar. Please contact us if we can make this document more accessible: pdxscholar@pdx.edu. 
AN ABSTRACI OF THE THESIS of Arthony Gene White for the Master of Science in Political Sejence presented December 15, 1971.

Title: A Regional Scope: City-County Consoljdation as a Method of Local Governmental Reorganization.

APPROVED BY MEMBERS OF THE THESIS COMMTTTEE:

Dr. Burton W. Orstine, Chairman

Merile G. Wricht

Dr. Irydon R. Musoxi

Dr. Leonard D. Cain

City-county consolidated governments are examined to isolate factors important to the success of the consolidation process, and ere rileasured against objective and subjective criteria for the operation of such goverments. Data are obtained through survey techniques and statistical anaiysis of demographic information. Results indicate trat such successoriented consolidation factors inherent in city-county governments do exist and can be interrelated ir a nathematica.I modeI. Consolidated governments appear to improve theig ability to handle urban problems, and officiais of consolidated governments are more confident of their ability to handle these problems than are officials of other metropolitar governments reorganized in afferent manners. 
A REGIONAL APPROACH: CETY COUNTY CONSOLIDATION AS A METHOD OF LOCAL GOVERNMENTAI REORGANIZATION

\section{by}

ANTHONY GENE WHITE

A thesis submitted in partial fulfillment of the requirements for the degree of

$$
\begin{aligned}
& \text { NASTER OF SCIENCE } \\
& \text { in } \\
& \text { POLITICAL SCIENCE }
\end{aligned}
$$

Portjand State University

$$
1971
$$

(C) Anthony Gene White 1971 
TO THE OFFICE OF GRADURTE STUDIES:

The members of the comrilttee approve the thesis of Anthony Gene Wiite presented December 15, 1971.

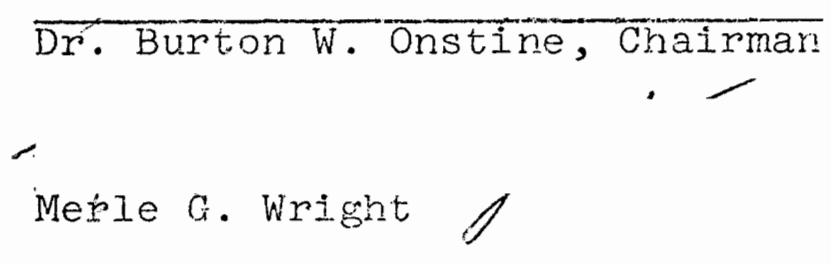

Dr. Lyydon R. Musolf

Dr. Leonard D. Cain

APPROVED:

Acting Department Head

Norman N. Greene, Head, Departothent of Folitical Solence

Dafud T. Clark, Dean of Graduate Studies

December I5, 3.971 


\section{ACKNOWLEDGMENTS}

The author wishes to acknow]edge the assistance provided by Dr. Burton $W$. Onstine and Mr. M. G. Wright during the preparation of this project, and of the special assistance provided in typing the final report by Mis. Betty Abbott. Most of all, credit should be acknowledged to Mrs. Carole A. White, who struggled through each and every draft in an effort to produce a polished piece of research. 
II DESCRIPTION OF TRE PROBIEM . . . . . . .

Definitions and Assumptions . . . 6

The Literature. . . . . . . . I0

The Hypotheses... . . . . . . 14

Experimental Design . . . . . . I6

III MHE RESUITS * . . . . . . . . . . .

A Qualitative Look . . . . . . 20

The Quantitative Aspect . . . . 31

IV SURVEY RESUITS . . . . . . . . . . . . 42

State, Consolidated, and control Group Results ......

The Failures: A Key to Understanding......... 49

$\checkmark$ TOWARD A MATEEMATICAL THEORY . . . . 54

Theoretical Considerations. . . . 54

A Test of the Theory . . . . . . 67 
CHAPTER

PAGE,

VI CONCLUSIONS . . . . . . . . . . . . . .

BIBLIOGRAPHY

81

APPENDIX

I Glossary of Terms . . . . . . . . .

I Test Instruments . . . . . . . . . .

112

II Results of State Survey . . . . . . . 117

IV Results of Consolidated Group Survey. .

V Results of Control. Group Survey . . .

VI Background Mathematics . . . . . .

124 


\section{LIST OF TABIES}

\section{TABLE}

PAGE

I City-County Consolidations in the United states,............ .

II Key Characteristics of City-County Con. solidated Units . . . . . . .

II Correlation Matrix - Spearman Rho . . ...... 35

IV Control Group Data . . . . . . . . . 39

$V$ Strengths and Weaknesses of City-County Consolidation ........... . 40

VI Statistical Tests of Variables . . . . . 42

VII Survey Results - States . . . . . . . . . 44

VIII Functionally Consolidated City-County

Units . . . . . . . . . . 46

IX Survey Results - Consolidated and Control . 47

$x$ Consolidations Rejected by Referenda. . . 50

XI Survey Results - Rejected Consolidations. . 52

XII Results of Applicaticn of Probability

Measure ............. 60

XIII Fozsible Crises Outcomes . . . . . . . . 69 


\section{IIST OF FIGUFES}

FIGURE

PAGE

1 Research design . . . . . . . . . . . .

19

2 Typical table of consolidated governmental organization . . . . . . .

3 Scoring chart for comparison of test instruments . . . . . . . . . 48

4 Projection of three-dimensional curve (A) into the two-dimensional plane (B) . 63

5 Projection of the function $F_{j}$ into the two-dimensional plane . . . . . . 63

6 Standardized graph of levels of regional organization . . . . . . . . 65

7 World Iine curves for Hampton, Virginia and Carson City, Nevada . . . . 66

8 Worla curve for Portland, Oregon . . . 70 
CHAPTER I

\section{INTRODUCTION}

Since the time of the first incorporation of a city in the United States, a fragnentation and overlapping of jurisdictions on the part of local governments has taken place. This is due in part to the cultural heritage from European ancestors who came to America seeking looser government controls, and in part to an aversion on the part of Americans to centralized government - which slowed the development of a strong, resourceful state or federal level of govewment. I Graaually, a patchwork of governments - statie, ccurty, municipal, and special districts - has covered the courtry. Many of these municipalities do not have hoine rule - the power to create ana enforce their own ordinances and regujations, This lack of home rule has limited the control granted to the municipalities over potential areas of expansion. Moreover, the states have retained all regulatory powers not expressly given to the federal government under the Constitution, so that in many instances the states have chosen to act as a

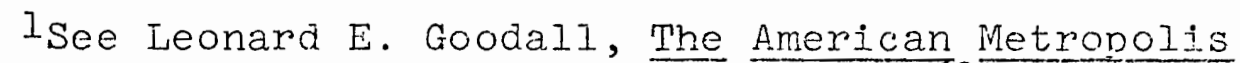
(Columbus, Ohio: Charles E. Merril Co., 1968), pp. 97-112; Danie1 R. Grant, The States and the Urban Crisis (Englewood Cliffs, N. J.: Prentice-Hal1, 1969; ; and Portiand Metropolitan Study Commission, Interim Report: 1966 (Portland, Oregon: Poitiand Metropolitan Study Comisision, 1966). 
second city council to the muricipalities.

However, counterexamples to this trend of duplication, fragmentation and overlapping of jurisdictions have existed in America since almost a century prior to its declaration of independence from England. In 1695, the English governor of the Massachusetts Bay Colony ordered the town of Nantucket and the County of Nantucket to consolidate to form a regional government, under what is now called city-county consolidation. Over the next few centuries, some state legislators, coming to the view that regional control around an urbanizing area by that area's local government would be essential, pushed for legislation creating both complete and partial city-county consolidations.

New Orleans and Orleans Parish (1805), Philadelphia and Philadelphia County (1854), the five contiguous boroughs of New York City (1898), Denver and Denver County (1901), and Honolulu and Honolulu County (1907) are all examples of complete city-county consolidations existing by virtue of state legislation. Also in this time period, Boston and Suffolk County were partially consolidated in 1821,2 as was San Frar.-. cisco and San Francisco County in 1854.3

After 1907, there was a forty-two year lapse in success-

2Massachusetts Legislative Research Council, Report Relative to Regional Government (Boston: Wright and Potter Printing (co., 1970), pp. 43-64.

3City and County of San Francisco, The Consolidated City and County of San Francisco (San Francisco: City and County of San linancisco, .1966). 
fully completed consolidations. Municipal reformers succeeded in sporsoring not only the manager and commission forms of government structure, but home rule for cities as well. 4 This newly-won power over their own destinies strengthened citizens' resistance to surrendering this power to a regional government. Between 1908 and 1950, more than ten consolidation attempts were defeated at the polls. 5

In 1949, voters in Philadelphia reaffirmed their faith in the consolidated approach to regional government by voting to restore the powers that had been eroded away over 95 years by the state and the courts to their consolidated government. In that same year, the first consolidation by referendum took place in Baton Rouge and Baton Rouge Parish, Louisiana. Since 1949, ten more consolidations have taken place, nize of them by referenda. Hampton and Elizabeth City County, Tirginia (1952), Newport News and Warwick Coluty, Virginia (1958), Nasiville and Davidson County, Tennessee (1962), Virginia Beach and Princess Ann County, Virginia (1963), South Norfolk and Norfolk County, Virginia (1963), Jacksonvilie and Duval County, Florida (1968), Carson City and Ormsby County, Nevada (1968), Juneau and Greater Juneau Borough, Alaska (1970), and Columbus and Muscogee County, Georgia (1971) have all been consolidated by referenda. In 1970, Indianapolis

4Massachusetts Iegislative Research Council, Regional Government, pp. 108-124.

5S.J. Makielski, Tr., "City-County Consolidation in the J. S.," University of Virginia News Letser (Charlottesville; University of Virginia, 1969), p. 3 . 
and Marion County, Indiana were consolidated by the Indiana State Legislature, to become the only modern legislative-imposed consolidation of the last half-century. At the same time, 1950 through 1971, more than fifteen cities and their continuous counties rejected consolidation as a solution to their regional problems. 6

Considering the full spectrum of alternatives available to local governments for solving regional problems - from annexation, informal agreements, special and metropolitan service districts through consolidation, merger, and federation (see Appendix I) - several questions arise that are worthy of investigation. Of these many forms of regional government available to urban governments, why do some choose aná some reject - city-county consolidation? Are there any readily distinguishable factors common to those successfui consolidations that separate them from other urban areas and governmerts? Is the consolidated government successful. enough in coping with metropolitan problems to attract the interest of other metropolitan areas facing the same problems? Are the government officials involved satisfied with consolidation as a tool for solution of their problems?

ro answer these questions, a set of definitions and assumptions mist first be agreed upon. A search of the literature is in onder, to formulate hypotheses on the basis of

$$
\text { 5́ Ibia., p. } 3 .
$$


previous research. A test instrument must be designed, and data gathered and analyzed to verify or disprove the formulated hypotheses. If the data indicater significant differences among the variables, then a mathematical model can be constructed to (1) account for the empirical data and (2) offer predictive statements as to the probability of a successful referendum in a proposed city-county consolidation measure.

The purpose of this study is thus two-fold. The first is to determine whether or not cities which consolidate with their overlapping counties are in some sense different from cities which have sought alternative forms of reorganization. The second is to see how well consolidated city-counties have handled fiscal, social, and planning functions in comparison with cities which have not consolidated with their contiguous counties. 
CHAPTER II

DESCRIPTION OF THE PROBLEM

\section{DEFINITIONS AND ASSUMPTIOXS}

Several sources provide the definitions and assumptions behind tris research, but the Bureau of the Census provides the bulk. For this research, "city" is taken to mean "a political subdivision of a State within a defined area over which a municipal corporation has been established to provide general local government for a specific population concentration." 7 A county is "the primary division of a state, used for state administrative purposes." 8 In Alaska, counties are called boroughs, and in Louisiana they are called parishes.

An urbanized area is defined to be:

The central city or cities plus:

1. Incorporated places with 2500 inhabitants or more;

2. Incorporated places with less than 2500 inhabitants, provided each has a closely settled area of 100 housing urits or more;

3. Towns in New England States, townships in New Jersey and Pennsylvania, and counties elsewhere which are classified as urban:

4. Enumeration districts in unincorporated territory with a population dersity of 1000 inhabitants or more per square mile;

5. Other enumeration aistricts in unincorporated territory with lower population density provi-

7Burea: of the Census, County and City Data Book 1967 A Statistical Abstract Supplement Washington, D. C.:U. S. Government Printing Office, 1967), p.xv.

I Ibia., p. xiii. 
ded that they serve one of the following purposes:

a. To eliminate enclaves;

b. To close indentations in the urbarized areas of one mile or less across the open end; and

c. To link outlying enumeration districts of qualifying density that were no more than one and one-half miles from the main body of the urbanized area.9

A standard metropolitan statistical area (SMSA), which is a statistical method used to examine the area around a central city, can be taken to be the contiguous counties (crossing state lines, if need be) circumscribing an urban area whose central city or cities has a population of 50,000 or more inhabitants, the labor force of which must consist of $75 \%$ or more non-agricultural workers. In addition, a county is included in the SMSA if there exists an integration of the work force within the economy of the central urbanized area.

Reorganization is the changing of the elements of an interdependent whole, in this case of a single or set of municjpal corporations. A two-level approach can be taken to reorganization: (1) A change in structure (for example, a mayorcouncil to a city manager or commission); and (2) a change in scope from a local to a regional approach, which may or may no't also include a change in structure.

More specifically, this study is concerned with citycounty consolidation as a regional approach to reorganization

${ }^{9}$ Ibid., p. xvi. 
of local government. City-county consolidation involves the dissolution of a city and a county, in terms of their governing bodies, to form a new municipal corporation whose boundaries encompass the old county's borders. A total city-county consolidation will (I) have one and only one governing body remaining after the consolidation; and (2) wil.l have countytype jurisdiction over any municipalities which choose to remain out of the new consolidated unit. Functional consolida-tion involves the consolidation of various departments in the city and county (such as police, health, water, etc.). Partial consolidations take place when only part of the county's territory is consolidated with the city, or when several departments remain under a separate government residual from the consolidation (such as the Nayor's office and the County Commissioners of the City and County of San Francisco). Appendix I provides a glossary of reorganization terms which snows the spectrum of approaches local governments have available to them with respect to regional problems, and distinguishes between them.

Once a regional government is established, the test of time determines whether or not it retains vitality as a municipal corporation. Municipal vitality is defined to be:

- - the administrative and firancial capacity of each local governmental unit to carry out with reasonable efficiency and at reasonable costs, in a manner consistent with performance standards prescribed by law, the duties and activities entrusted to it by the state 
constitution, state laws and its own local charter. 10

The following assumptions are presented as the basis for the subject selection for this study and for the determination of the hypotheses that follow: (1) It is possible to determine the need (or lack of need) for regional goverrment as a solution to area-wide problems;ll (2) City-county consolidation as a method of approach to regional government is of great enough significance to warrant an in-depth study; ${ }^{12}$ (3) The data desired are obtainable, and the instruments de-

10Massachusetts Legislative Research Council, Report Relative to Voluntary Municipal Merger Procedures (Boston: Wright and potter Frinting Co., 1970), p. 5 i.

llThe following criteria have been established for just this purpose. These criteria include: (I) the government jurisdiction responsible for providing any service should be large enough for the benefits from that service to be received primarily by its own population; (2) the unjt of government should be large enough to realize economies of sciile; (3) the unit of government carrying on a function should have a geographic area of jurisdiction adequate por effective performance, as illustrated by the desirability of a sewage disposal system's conformance to a natural drainage basin; (4) the unit of government shoula have the legal and administrative ability to perform the services assigred to it; (5) every unit of government should be responsit le for a sufficient number of functions so that its governing processes jnvolve a resolution of conflicting interests and a balancing of governmental needs and resolirces; (6) the performance of public functions should remain subject to public control. . .; and (7) functions should be assigned to a level of government that provides opportunities for active citizen participation, and still permits adequate performance. See Massachusetts Legislative Research Council, Regional Government, p. 42 and ACIR, Metropolitan America: Challenge to Federalism (Washington, D. C.: U. S. Government Printing Office 1966$)$, pp. $30-32$.

every 8 Americans $(12.75 \%)$ is directly or indirectly influenced by a city-colnty consolidated government; he is either governed by one or is in the urbanized area of such a government. See "lo 'Sluper Cities' - Home for 1 of Every 4 Americans," U.S. News and World Report, August 2,1971, p. 79. 
signed to collect such data do in fact collect the data in question; and (4) Given the same instruments and the same samples, any independent researcher could obtain the same data.

\section{THE LITERATURE}

The majority of the publications dealing with citycounty consolidation consists of charter commission findings, pro- and anti-consolidation literature for specifjc consolidation attempts, and newspaper accounts following the progress of the consolidation movement.

There is, however, some scholarly literature in existence. The Committee for Economic Development 13 and the $\mathrm{Ad}$ visory Commission on Intergovernmental Relations 14 have both pubiished results of proceedings of their organizations dealing with the general problems of metropolitan reorganization. The Adviscry Commission has isolated several factors relating to the success or failure of reorganization efforts in general.15 Listed as favorable factors are: cooperation on the

13Committee for Economic Development, Reshaping Government in Metropolitan Apeas (New York: Committee for Economic Development, 1970.)

$1{ }^{14} \mathrm{Advisory}$ Commission on Intergovernmental Relations, Urban America and the Federal System (Washington, D. C.: U. S. Government printing office, 1969) and Factors Affecting Voter Reactions to Governmental Reorganization ir Metropolitan Areas (Washington, D. C.: U. S. Government Printing Office i i 52 ).

1.5 fidisory Commission on Intergovernmental Relations, Factors Affecting Voter Reactions, pp. I6-23. 
part of state governments; use of local knowledgable individuals for staff and support; use of exterisive public hearings; and recognition of problems and needs of specific areas and groups. Listed as unfavcrable factors are: the absence of $\underline{\text { a }}$ critical situation to be remedied (emphasis added, A. W.); opposition by leading political figures; lack of vigor in pressing the reorganization campaign to its conclusion; and failure to allay fears of a dramatis tax increase.

The only general survey of consolidated units in the United States was published in 1941 by John Rush, 16 one of: the coauthors of the Denver consolidation bill. Rush chronicles the partial, functional, and complete consolidations prior to 1941 - which does not include, incidentally, any consolidations accomplished by referenda.

Hawkins 17 has chronicled the history of the Nashville case, dwelling in particular upon the taxing and annexation policies of the city government as the key to consolidation. Martin's study of Jacksonville 18 goes into great detail about the complexity of the structure of Jacksonvilie's government (both a city council and a city commission), the disaccreditation of the school systern, and the Grand Jury

16.John A. Rush, The City-County Consolidated (Ios Angeles: By the Author, 1941).

17 Brett Hawkins, Nashvilie Metro: The Politics of CityCounty Consolidation (Nashvilie: Vanderbit Universjty, I966). County: The Dynamics of Urban Political Ref'orm Jacksonville: Convention press, 1968). 
indictments of public officials which finally led to a successful vote for consolidation.

Schmandt, Wendell and Steinbickerl9 examine the failure of St. Louis to consolidate with its overlapping county, and conclude that the legal, traditional, and political separation between city and county, weak enabling legislation, and the lack of a critical situation were the key factors involved. McDill and Ridiey20 conclude that Nashville's first failure was due to voter alienation among lower status citizens, while Lawrence and Turnbul12l examine the political motivations of Mayor Lugar's successful bid to consolidate Indianapolis and Marion County. Scott, on the other hand, constructed a continuum of the "radicalness of metropolitan governmental change" which shows that total consolidation is too radical, too far beyond the "threshhold of voter acceptability" to be generally accepted by the voters. 22

State agencies have issued position papers on local and metropolitan problems and solutions. Colorado, 23 North

$19 \mathrm{~N}$. J. Schmandt, P. G. Steinbicker, and G. D. Wendell, Metropolitan Reform in St. Louis: A Case Study (New York: Holt, Rinehart, and Winston, 1961).

20E. L. McDill and J. C. Ridley, "Status, Anomia, Political Alienation, and Folitical Participation." American Journal of Sociology. September, 1962, pp. 205-213.

Zl D. M. Lawrence and H. R. Turnbuli, "Unigov: CityCounty Consolidation in Indianapolis," Popular Government (November 1969), pp. 18-26.

22Thomas M. Scott, "Metropolitan Governmental Reorganization Proposals," The Western Poliifical QuarterIy, XXI, (June 1968 ), pp. $252-26 \pi$.

23.Division of Local Government, Probleris of Local Government, (Denver: State of Colorado, 1968). 
Dakota, 24 and Massachusetts 25 are among those states issuing such papers. The Massachusetts Legislative Research Council reviews some of the successful consolidation attemots, and then proceeds to point out the obstacles which make reorganization on a regional level difficult or almost impossible in Massachusetts (in spite of the Nantucket and Boston-Suffolk County examples): the provincialism of its citizens; fears of higher taxation and changes from the status quo; misconceptions about the nature and scope of regional governments; and the death-grip that the citizenry maintains on the concept of "home rule".26

Other organizations which have endeavored to examine city-county consolidation include the Department of Agriculture, 27 the League of Women Voters, 28 and various local metropolitan study commissicins. In its last annual report, the Portland Metropolitar Study Commission reviews its eightyear history, accomplishments, and recommends that machinery be created to permit a vote on city-county consolidation,

24 Legislative Council of North Dakota, State, Federal, and Local Government (Bismark, N. D.: State of North Dakota, $\overline{1970}$

25Massachusetts Legislative Research Council, Report Relative to Regional Government (Boston: Wright and $\overline{\text { Potter }}$ Printing Co., 1970).

26 Ibid., pp. 111-113.

27 Economic Research Service, Department of Agriculture, Imoact of City County Consolidation on the Rural-Urban Fringe: Nashvil Ie-Davidson County, Tennessee (Washington, D.C.: U. S. Government Printing office, 1971).

28Ieague of Women Voters, City-County Consolidation (Portiand, Oregon: League of Women Voters, 1970). 
that county and metropolitan service districts be strengthened and broadened in scope, 29 that the local Boundary Commission be given more power, 30 and that a local governmental commission be established to act as watchdog over local intergovernmental relations. 31

A search of the literature, while dwelling in large part on the aspect of reasons for consolidation failure, does not explore favorable variables for consolidation referenda successes, nor does it attempt to question how well consolidated cities have handled functions entrusted to them. The task attempted here is to fill these gaps in the literature.

\section{THE HYPOTHESES}

Based on the preceding definitions and possible variables indicated by the literature, a formulation of rypotheses is now in order. In considering these hypotheses, it must be remembered that city-county consolidation is an approach to the scope of urban government, not necessarily an attempt to alter the structure of such governments (with the exception of the merger process itself).

- 29Portland Metropolitan Study Commission, Annual Report: 1971 (Portland, Oregon: Portland Metropolitan Study Commission, 1971$), \mathrm{p} .4$. 30 Ibid., p. 5. 
HYPOTHESIS 1: There are significant differences of certain variables, to be empirically determined, between citycounty consolidated governments and cther metropolitan governments which have sought alternative solutions to metropolitan problems .

If such variables can be shown to exist, then a mathematical theory can be developed to interrelate these variables to one another.

HYPOIESIS 2: The vitality (i.e., flexibility, ability to develop, and responsiveness) of a municipal corporation is maintained under city-county consolidation. 32

As a parallel line of investigation to the objective measurement of vitality, a subjective measurement of the opinions of the involved public officials can be of value. Indeed, if those directly involved in reorganization are not satisfied with the results of their reorganization efforts, this should serve as data for future reorganization attempts.

32 The test of this hypothesis involves the use of objective criteria developed by the Massachusetts Legislative Research Council in Voluntary Municipal Merger Procedures, p. 52. Such criteria involve measuring (a) the kinds of government functions which the municipality must perform; (b) the size, density, distribution, and characteristics of the population of the community, and its contrast with the optimum population for the efficient and economical administration of such functions; (c) the extent to which the area of the municipal corporation embraces or may be expanded to include. . .; (d) the responsiveness of the municipal government, organically and politically, to the challenges of urbanization and to public demands for more and better services; and (e) the fiscal capacity of the municipality in terms of the property and economic activity it may tax locally, its borrowing power, and the rinancial support extended by the state in municipal programs mandated by it. 
HYPOTHESIS 3 : In the views of the involved public officials, certain social control, fiscal, and planning functions are more easily performed under city-county consolidated governments than under metropolitan governments which have sought alternative solutions to metropolitan problems. Consequently, public officials of consolidated governments possess a more positive perception of their ability to deal with metropolitan problems than do public officials of metropolitan governments which have sought alternative solutions to metropolitan problems.

\section{EXPERIMENTAL DESIGN}

As a search of the literature revealed, information concerning the existence of consolidated governments is both scanty and in many cases inaccurate and out of date. After determining the approximate spatial distribution of the consolidated governments, it was determined that the situdy would have to be made on a natjonal basis. Due to the nature of the study and the cost/benefit ratio of the various methods available (personal, telephone, and mail interview), the test instrument settled upon was the mail-back questionnaire. 33

The test instruments were designed and screened for bias. 34 The primary phase of the study involved sampling all.

$33_{\mathrm{F}}$. F. Stephan and P. J. McCarthy, Sampling Opinions (New York: John Wiley and Sons, 1958).

$34 . \mathrm{J}$. A. Clausen and R. N. Ford, "Controlling Bias in Mail Questionnaires," Journal of American Statistical Association. \#42, (1947), pp. 497-5II. 
fifty states as to (1) presence of city-county consolidated units; (2) avaijability of legislation permitting consolidation; (3) awareness of any planned city-county consolidations; and (4) official sanction of the technique of citycounty consolidation as a method of approaching metropolitan problems. Questionnaires were mailed first to the statelevel department of local governments, 35 and as a followup to those not responding a questionnaire was sent to the office of the Governor of the state concerned. In this manner, a $100 \%$ response was obtained.

At this point, sets of total, partial, and functional consolidations between cities and counties were isolated. The secondary phase of the study involved sending questionnaires to these consolidated units. This portion of the study attempted to determine (1) reasons for consolidatinE; (2) legal status of the unit; (3) occurrence of social problems; (4) occurrence of fiscal changes; (5) effectiveness of the planning function under consolidation; and (6) perception of overall effectiveness of consolidation through recommendations to other governments considering it. These questionnaires were sent to the appropriace chief executive's office either the mayor or the city manager. Repeated mailings to these offices brought about a $100 \%$ response.

As part of the secondary phase, a control group was

35HUD. State Urban Information ard Techinical Assistance Services - The First Six Months (Washington, D. C.: HUD Clearinghouse service, 1959). 
selected so as to approximate the rational distribution and median population of the consolidated (experimental) sample. Within these limitations, the control group was selected randomly. Nonrespondents were dropped from the sample, and others were chosen randomly to complete a control group of the same size as the experimental group. The same questions were asked.

A final phase was performed to determine what had defeated sone consolidation measures in some cities. A questionnaire was mailed to those cities which had failed under referenda to consolidate since 1950 .

Figure I diagramatically outlines the research design. The test instruments are reproduced in Appendix II.

Upon receipt of the returned questionnaires, the responses were scored. The questionnaire scores and statistical data were then subjected to statistical analysis, and the significant factors isolated. 


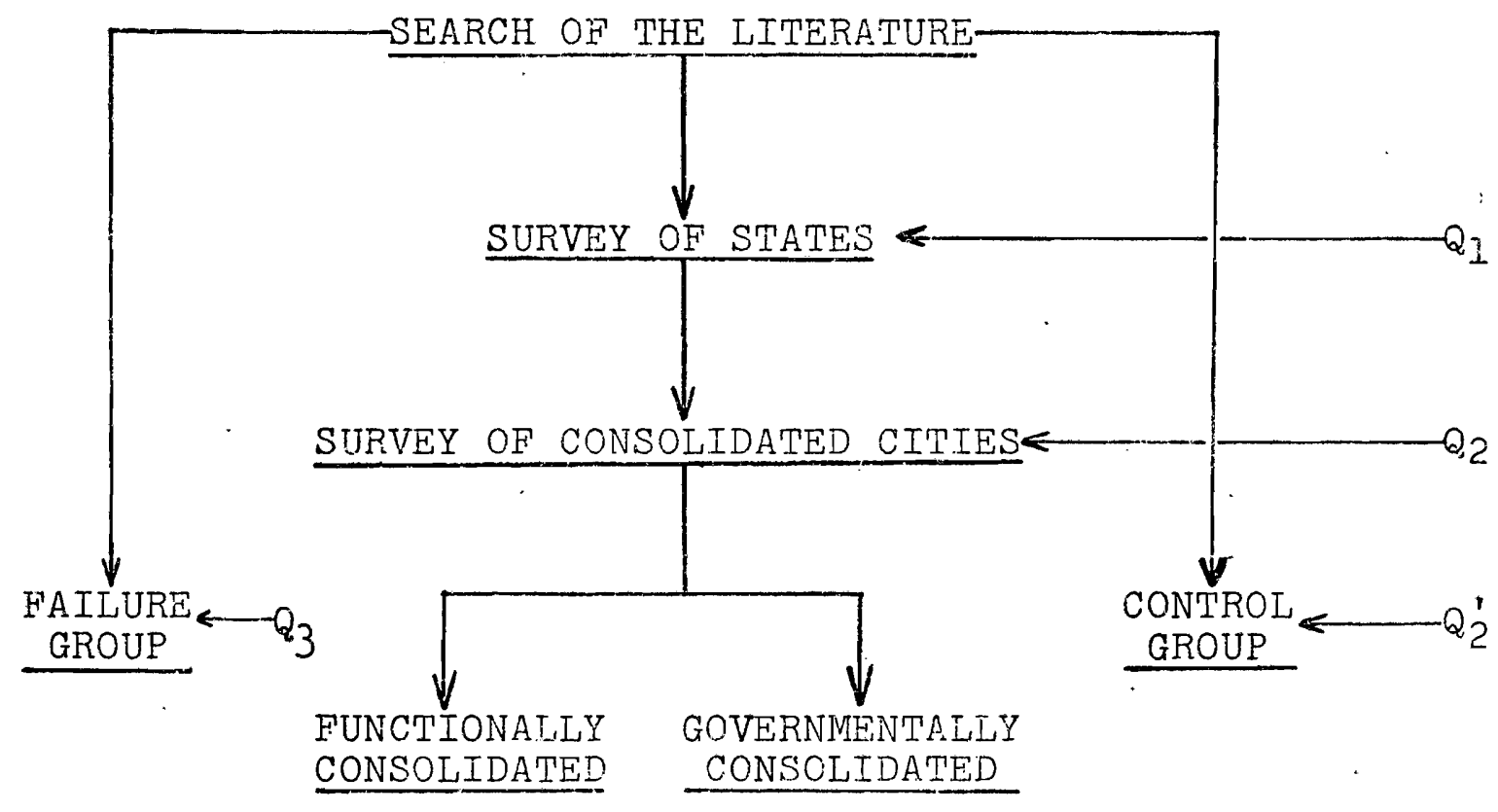

$Q_{1}$ - Initial survey of states

$Q_{2}^{1}$ - Survey of consolidated units

Q - Survey of control group

$Q_{3}^{2}$ - Survey of consolidation failures

Figure 1. Research design. 


\section{CHAPTER III}

\section{THE RESULTS}

\section{A QUALITATIVE LOOK}

In order to approach the data collected in this study, it is first of value to consider the qualitative history of each consolidation. In many cases, the available information is sketchy, but a feel for the development of consolidations can be attained through that which is available.

NANTUCKET, MASSACHUSETTS. The seafaring commurity of Nantucket, Massachusetts was incorporated as a town while under the jurisdiction of New York in 1687, and was ceded to Massachusetts Bay in 1692. In 1695, the General Court of Massachusetts recognized the island as a distinct county, but due to the smail population political incumbents were permitted to combine city and county offices. Over the years the town and county governments have been integrated in terms of personnel and fiscal function by statute. 36

NEW ORLEANS, LOUISIANA. New Orleans was settled by Frenchmen while Louisiana was still a French territory. Shortly after the Louisiana Purchase, the city of New Orleans was incorporated (in 1805). At the same time, the legislators

36 Massachusetts Legislative Research Council, Voluntary Munictpal Merger Procedures, pp. 93-94. 
of the Louisiana Territory created parishes to act as county governments, and Orleans Parish was placed under the same government as the city. 37

PHILADELPHIA, PENNSYLVANIA. Philadelphia was the rext city to be consolidated. The Act of Consolidation of 1854 combined 28 of 29 political subdivisions of Philadelphia County into the City and County of Philadelphia. The history lists no reasons for the state legislature to create this Act. The powers and consolidated departments were eroded away cver the years by the courts and succeedirg state governments. In 1949, a Home Rule Act was adopted by the state which permitted the voters of Philadelphia to reaffirm their faith in their consolidated government. 38

NEW YORK CITY, NEW YORK. New York was in the grip of "machine politics" in the 1.890s. The population was a diverse, low-income mixture of nationalities, and the counties contiguous to New York City were incapable of financing facilities needed to perform urban services for the rapialy-growing neighborhoods. Part of the Bronx had been annexed in 1874, and the rest was annexed in 1895. 'The citizens of New York City, under the Home Rule Charter of 1894, had voted to consolidate with Brooklyn. However, the mayors of New York

37Rush, The City-County Consolidated, pp. 83-88. 38 George S. Blair. "Analyzing Governmental structure in a Metropolitan Area with Particular Reference to the Philadelphia Área" in Metronolitan Analysis. (Philadelphia: University of Pennsylvania. Press, 1958). 
and Brooklyn could not agree upon a consolidated charter which would satisfy the partisan groups in those cities. In May of 1897, a charter was agreed upon, but the effective date of the consolidation was postponed indefinitely. In 1898, the state legislators were pressured by a "machine boss" and municipal reformers who wanted Republican dominance in the city into enacting consolidation of New. York City, Brooklyn, Richmond, Kings, and Queens into the city of Greater New York. 39

DENVER, COLORADO. After a failure to consolidate with Arapahoe County, the city of Denver lobbied through John Rush at the Colorado State Legislature for creation of a county especially for future metropolitar expansion. In 1901, passage of an amendment to the State Constitution, Article Xx, was assured which would carve out parts of Arapahoe and Adams Counties to form the County of Denver and consolidate it with the city of Denver. The amendment took effect in 1902, and since that time 170 annexations have added over 90 square miles to Denver's total area. 40

HONOLULU, HAWAII. Following Hawaii's annexation to the United States in 1898, no local governments of any kina existed until 1905. In that year, the County of Cahu was established to govern the entire island of Oahu. The 1907 Territorial Legislature abolished the County of Oahu and created

39 Wallace S. Sayre and H. Kaurman. Governing New York City (New York: Russell. Sage Foundation, lobi). PJanning Office, Denver - I969 (Denver: City of Denver, 1969). 
the City and County of Honolulu, which encompasses the island. The Mayor-Board of Supervisors estaklished in 1907 was final$1 y$ altered to the Mayor-Council form in 1959.41

BATON ROUGE, LOUISIANA. In 1945, Baton Rouge had a population of 35,000 within an area of about 5 square miles. The last major improvement of public facilities had been made in the period 1924-1925. Totally unprepared for the post-war growth that hit many of the South's cities, Baton Rouge had doubled its population by 1948. The strain was too much for the system, and in order to eliminate outmoded governmental structures and attain the tax base necessary to survive, consolidation was proposed. The vote was a slim 51\% for consolidation, a margin of only some 300 votes in 13,717 cast. 42

HAMPTON, VIRGINIA. Hampton was one of the 34 independent cities in Virginia that had chosen in the 1870s to separate from the counties surrounding them. In 1951, the city of Newport News had suggested a consolidation of Hampton, Newport News, and other surrounding jurisdictions which was rejected. At that point, Newport News was threatening to annex the territory surrounding Hampton under Virginia's annexation without representation law. As a consequence, Elizabeth

${ }^{41}$ City and County of Honolulu, The City and County of Honolulu (Honolulu: City and County of Honolulu, 1969).

${ }_{42}$ City and Parish of Baton Rouge, Our City-Parjsh Government: A Thumbnail. Sketch (Baton Rouge: City and Parish of Baton Rouge, N. D.) and Richard J. Richardson, Orleans Parish Orfices: Notes on City-Farish Consolidation (New Or]eans: Bureau of Government Research, 1961). 
City County, the town of Phoebus, and the City of Hampton voted in 1952 to consolidate, in order to avoid the higher tax rates of Newport News. 43

NEWPORT NEWS, VIRGINIA. A 1956 referendum solight to consolidate Newport News, the consolidated City and County of Hampton, and Warwick (incorporated in the referendum of 1952 , but for all practical purposes - politically, structurally, and fiscally - still a county). The referendum resulted in a 7 to 6 margin of defeat for consolidation, led by Hampton voters. In 1957 Newport News and Warwick voted to consoIidate, effective in 1958.44

NASHVILLE, TENNESSEE. Nashville, Tennessee was caught in the same influx of population following World war II as most other United States cities. Many of these immigrants settled outside the city limits in Davidson County, thus overloading the antiquated facilities of the county. A 1951 report of the Tennessee Taxation Asscciation recommended complete consolidation of the city and the county.45 A Ternessee statute enacted in 1955 permitted annexation without representation (no-consent), and a new city per year was incorporated in Davidson County in the period 1957-1959. In 1958, following a fight in the state legislature over an enabling

43David G. Temple, The Tidewater Mergers: The Politics

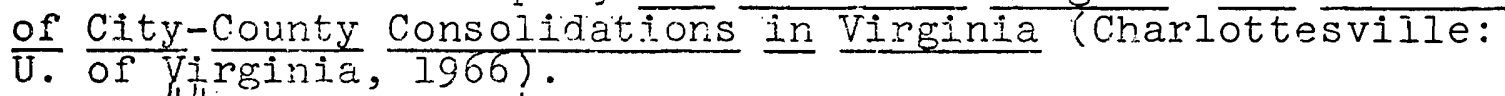
44 Ibid., pp. $14-21$.

45 Tennessee Taxation Association, Report on a Detailed Survey of Financial Conditions of Davidson County, Tennessee with Recommendations (Nashville: Tennessee Taxation Association, 1951$)$. 
act to allow a consolidation vote, such a vote denied Nashville and Davidson County the right to consolidate by a 6 to 5 ratio.

In 1960, the mayor of Nashville instituted an annexation of 42 square miles, containing a population of 80,000 people, using the recently-passed no-consent annexation Iaw. Understandably, some citizens were upset by this action, and consequently a new movement was begun to consolidate in order to oust the mayor and his council. A vote on the issue in 1962 resulted in a 4 to 3 decision to consolidate. Fifty percent more people voted in the 1962 election as had in the 1958 one. 46

VIRGINIA BEACH, VIRGINIA. Using Virginia's annexationwithout-representation law, Norfolk had, in 1959, anrexed 13 square miles and 38,000 people. Fearful of being cut of $i$ from all possible expansion, and of being subjected to the higher tax rates of larger Norfolk, Virginia Beach voters and the voters of Princess Ann County moved to cut off Norfolk's expansion by voting in 1963 to consolidate. 47

CHESAPEAKE, VIRGINIA. Cut off from expansion into Princess Anr County, Norfolk turned to Norfolk County for area

46 James C. Coomer, Nashville-Davidson County: A Study or Metropolitan Government (Nashville: American Political Science Association, 1969).

47Richard J. Webbon, Letter to Professor Vincent Morando, University of Georgia, dated May 8, 1970, subject: Virginia Beach's Consolidation and Virginia Metropolitan Areas Study Commission, Governing the Virginia Metropolitan Areas: An Assessment (Rj.chmond: Commonwealth of Virginia, 1967). 
into which it could grow. The citizens of South Norfolk, not wanting to be cut of from room to grow themselves, convinced the voters of Norfolk County that tax rates in South Norfolk would remain considerably lower than in Norfolk. A 1962 vote authorized the consolidation of South Norfolk and Norfolk County, which became effective in January of 1963. The new city was named Chesapeake. 48

JACKSONVILLE, FLORIDA. A 1956 study explored the possibilities of city-county consolidation in Florida, with particular reference to Miani and Jacksonville. 49 A decline in central-city population coupled with a corresponding increase in population in the suburbs brought financial stress to the itty of Jacksonville in the 1960s. Jacksonville had a mayorcouncil/city commission form of government, and publicly identified as problems duplication of services and fragmentation and overlapping of jurisdictions with Duval County. Against this background, Jacksonville's schools were disaccredited in 1965, and several government officials were brought before a grand jury on charges of corruption in 1966. In August, 1967 a referendum to consolidate Jacksonville and Duval County resulted in a 54,500 to 29,700 vote to consolidate. The new government legally took over in October, 1968.50

${ }^{48}$ Charter Commission for South Norfolk and Norfolk County, A Historic Past: A Promising Future (South Norfolk: Charter Commission, 1962.5

$49 \mathrm{~J}$. E. Doveli, City-County Consolidation: Its Possibil-ities in Florida (Gainsville: University of Florida, 1956). 50 "Day of Reminder," Jacksorville Jourral, Jacksonville, October 1, 1970 . 
CARSON CITY NEVADA. The charier of Carson City, Nevada was amended in 1951 to combine the offices of Clerk, Auditor, Assessor, District Attorney, and Sheriff with the corresponding offices of Ormsby County. In the period 1964-1968 a functional consolidation of most of the other service departments took place. The city council and the County Commissioners of Ormsby County had long been in agreement that total consolidation was in order for a geographically smal.l, isolated area, and would make stretching of available funds possible. A statewide election (due to provisions of the state of Nevada's Constitution) in 1968 approved the formal consolidation of the two units, and in that year their governments were legally combined. 51

INDIANAPOLIS, INDIANA. The consolidation of IndianapoIis and Marion County, Indiana is considered to be the work of one man - Mayor Richard Lugar. He came to power in 1967, the fixst Republican to hold the mayor's office in many decades. Indianapolis had many of the publicly-identified ills of other cities - decreasing central city population, racial tensions, declining purchasing power provided by a relatively static tax base, and inefficiency through duplication of services and overlapping of jurisdictions with Marion County. Using the power of his office, Mayor Lugar and the

5lCity of Carson City, Historical Data, Legal Requirements, Reasons and Effects of Consolidation of Carson City and Ormsby County into a New Entity - Carson City, Nevada (Carson City: Cjty of Carson City, N. D.). 
strong Marion County Republican Party convinced the State Legislature (also strongly Republican at the time) that consolidation was necessary for the continued operation of his city. The Legislature, which served as a second city council for Indianapolis, agreed with Mayor Lugar and approved a consolidation bill which was signed in March of 1969. The law had an emergency clause which made the consolidation effective in January of 1970, and which exempted from the consolidation the towns of Speedway, Beach Grove, and Lawrence. 52

JUNEAU, ALASKA. Juneau, Alaska would seem to be an unlikely place to find muricipal reformers pushing for consolidation. Founded as a gold-rush center in 1881, the City and Borough of Juneau has a population of only 13,000 spread out over some 3,000 square miles. Local officials considered it too expensive to support two sets of governmental services over a tax base of $\$ 130$ million. Consolidation was approved in 1970, and the consolidated unit is considered to be both a city and a borough under Alaskan law. 53

COLUMBISS, GEORGIA. The most recent consolidation has been that of Columbus and Muscogee County, Georgia. The school administrative services were merged in 1948, followed by water, sewer, and airport facilities in the 1950s and 1960s. A formal consolidation of the two governmental units

52 "Three Mayors Review their Governments," Nation's Cities, November, 1969, pp. 26-37. "Unigov," $\underline{H} \cdot \underline{U} \cdot \underline{D} \cdot$ Challenge Magazine, May, 1971 , pp. 6-9. $\underline{\$} 10-210, N$. D. 
was defeated in 1962.54 Nearly all council members and the mayor were replaced in 1964, and a study commission was authorized by the Georgia General AssembIy in 1966 to draw up a new consolidation plan. A city-county building complex was proposed, to gain economies of scale in construction and to provide more visible access to governmental agencies.

With local leaders, the news media, and a steering committee behind the new consolidation attempt, an Enabling Act was passed by the Georgia Legislature in 1969. Following a highly active campaign to develop a "grass roots" movement for consolidation, a 1970 vote approved consolidation by 10,000 votes (15,000 votes cast out of a possible 53,000). The new charter became effective as of Januciry 1, 1971.

One common thread which runs throughout most of these histories is the presence of a critical situation which needs to be remedied (a factor which the A.C.I.R. describes as favorable to the passage of a consolidation measure--see page 10). Nantucket, New Orleans, Denver, Honolulu, Carson City, and CoIumbus are the cities which apparentiy had no such situations - those legislatively consolidated, or functionalIy consolidated prior to the referendur.

Philadelphia faced the erosion of city powers by the state and the courts. New York's political "machine" was at odds with Brooklyn's, and negotiations for merger were at a

${ }^{54} \mathrm{~S}$. J. Makielski, Jr., "City-County Consolidation in the U. S.," University of Virginia News Letter (Charlottesville: U. of Virginia, October, 1969). 
standstill when the legislature was forced to intervene.

Baton Rouge's service facilities were severely overtaxed with the influx of the post-World War II population. Hampton, Newport News, Virginia Beach, and Chesapeake were all faced with the involuntary annexation of territory surrounding their boundaries, thus cutting them off from future expansion and drawing the county territory into higher tax1ng areas.

Nashvilie's voters reacted to a massive involuntary arinexation, and voted for consolidation as an expression of a lack of confidence in the city's mayor and council. Jacksonville had just faced the disaccreditation of its schools and the indictment of several public officials for corruption when the referendum took piace.

Indianapolis was controlled by the state legislature, as a second city council. It needed the home rule provisions giranted to counties in Indiana just to solve its everyday problems and to obtain the taxing authority necessary to maintain government services. Juneau simply could not afford to support two sets of government, and provide the urban services required by the area's citizens, on such a small tax base. The solution was either to reduce services or to reduce government, and the voters chose the latter measure. 
II. THE QUANTITATIVE ASPECT

There are a total of seventeen city-county consolidated governments in the United States, of which ten were created through referenda. Naturally, some differences can be expected between legislatively-consolidated units, most of which are over 60 years old, and consolidated governments chosen by the voters, most of which are less than 20 years old.

To present an overall view of the spectrum of consolidated governments, tables I and II are constructed to give data from a constant time period, 1960-1970. Due to inaccuracies and a lack of controls on errors and variances, it is unwise to rely on data from time perioas prior to 1900. This precludes comparison of such data as population, population changes, population density and other demographic information in the decades prior to and following the consoljdations. For example, the populations of Philadelphia and New York must have had difrerent education, median age, and other demographic characteristics 70 and 100 years ago which could have influenced the consolidation issue.

Potential variables were chosen on the basis of the literature and availability of statistical data, to include political economic, historic, and demographic aspects. Consideration of potential variables was limited to those for which data was available for at least two-thirds of the 


\section{TABLE I}

CITY-CONTY CONSOLIDATTCNS IN THE UNJTED STATES

\begin{tabular}{|c|c|c|c|c|c|c|c|c|c|c|c|c|c|c|c|c|c|}
\hline /CITY: & Nantucket & $\begin{array}{l}\text { New } \\
\text { Orleans }\end{array}$ & $\begin{array}{c}\text { Philadel- } \\
\text { phila }\end{array}$ & $\begin{array}{l}\text { New } \\
\text { Yort } \\
\end{array}$ & Denver & Honolulu & $\begin{array}{l}\text { Raton } \\
\text { Roupe }\end{array}$ & Harpton & $\begin{array}{l}\text { Newport } \\
\text { News }\end{array}$ & Nasrville & $\begin{array}{l}\text { V1rginis } \\
\text { Beach }\end{array}$ & Cresapeake $^{2}$ & $\begin{array}{r}\text { Jackson- } \\
\text { ville }\end{array}$ & $\begin{array}{l}\text { Carson } \\
\text { City }\end{array}$ & $\begin{array}{r}\text { Indfana- } \\
\text { pol 18 }\end{array}$ & Juneau & Colurthos \\
\hline County & Nantucket & $\begin{array}{l}\text { Orleans } \\
\text { Parist }\end{array}$ & $\begin{array}{c}\text { Pr.1ladel- } \\
\text { pria }\end{array}$ & $\begin{array}{l}\text { Kings, New } \\
\text { York, Bronx, } \\
\text { Richrond, } \\
\text { Queens }\end{array}$ & Denver & Honolulu & $\begin{array}{l}\text { Fast } \\
\text { Raton } \\
\text { Rouge } \\
\text { Parish }\end{array}$ & $\begin{array}{l}\text { Filza- } \\
\text { betr } \\
\text { C1ty }\end{array}$ & iarwlek & Daviason & $\begin{array}{l}\text { Princess } \\
\text { Ann }\end{array}$ & Norfolk & Duval & Croshy & Marton & $\begin{array}{l}\text { Greater } \\
\text { Juneau } \\
\text { Porougt }\end{array}$ & Pruscogee \\
\hline State & $\begin{array}{l}\text { Massachu- } \\
\text { setts }\end{array}$ & $\begin{array}{l}\text { Lou1s- } \\
\text { lana }\end{array}$ & $\begin{array}{l}\text { Penns::1- } \\
\text { vania }\end{array}$ & New York & $\begin{array}{l}\text { Color- } \\
\text { ado }\end{array}$ & Hawalf & $\begin{array}{l}\text { Louss - } \\
\text { \{ana }\end{array}$ & Virginis & Virginia & Tennessee & Yirginis & Virginis & Florsida & Nevada & Indians & Alaska & Ceorgta \\
\hline $\begin{array}{l}\text { Year of } \\
\text { Incorpor- } \\
\text { ation }\end{array}$ & 1687 & 1805 & 1701 & 1624 & 1861 & 1907 & 1817 & 1849 & 1896 & 1784 & 1906 & $1919^{2}$ & 1821 & 1875 & 3647 & 3881 & 3828 \\
\hline $\begin{array}{l}\text { Year of } \\
\text { Consoll- } \\
\text { dation }\end{array}$ & 1695 & 1805 & 1854 & 1898 & 1901 & 1907 & 1949 & 1952 & 1958 & 1962 & 1963 & 1963 & 1968 & 1968 & 1969 & 1970 & 1971 \\
\hline $\begin{array}{l}\text { Age at } \\
\text { Consoll- } \\
\text { dation }\end{array}$ & 8 & - & 153 & 274 & 40 & - & 138 & 103 & 62 & 278 & 57 & 44 & 147 & 93 & 122 & 89 & 143 \\
\hline $\begin{array}{l}\text { Economic } \\
\text { Function }\end{array}$ & P8 & TWF & $\mathbf{F}$ & $F$ & WF & $\mathrm{TPbF}$ & D & Pb & $\mathrm{TPb}$ & 8 & PbPs & $\mathrm{Pb}$ & PANFTPb & $\mathrm{Pb}$ & $\mathbf{F}$ & Y.1PO & D \\
\hline $\begin{array}{l}\text { Form of } \\
\text { Local Gov- } \\
\text { errment } \\
\text { Structure }\end{array}$ & $\mathrm{My}-\mathrm{C}$ & $M y-C$ & $N_{y}-C$ & $\mathrm{My}-\mathrm{C}$ & $\mathrm{M} y-\mathrm{C}$ & $M y-C$ & $M y \sim C$ & in & $\mathrm{My} \sim \mathrm{C}$ & $M y-C$ & $\mathrm{kn}$ & $x y-c$ & $r_{5}-C$ & $y_{n}$ & $r_{y}-c$ & $Y_{n}$ & $r_{y}-c$ \\
\hline $\begin{array}{l}\text { Independent } \\
\text { Department }{ }^{4}\end{array}$ & No & Yes & Yos & Yes & No & No & Yes & No & No & No & No & No & No & No & Yes & No & Yes \\
\hline $\begin{array}{l}\text { Independent } \\
\text { C1ties } 5\end{array}$ & No & No & No & No & No & No & No & No & No & Yes & No & No & Yes & No & Yes & No & No \\
\hline \multicolumn{18}{|c|}{ 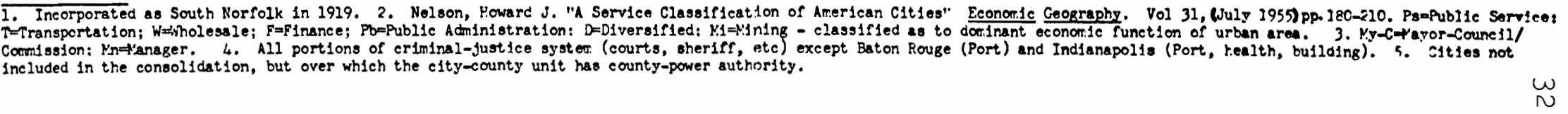 } \\
\hline
\end{tabular}




\section{TABLE II}

KEY CHARACTERISTICS OF CITY-COUNTY CONSOLIDATED UNITS

\begin{tabular}{|c|c|c|c|c|c|c|c|c|c|c|c|c|c|c|c|c|c|}
\hline $\begin{array}{l}\text { (CITY: } \\
\text { FACTOR: }\end{array}$ & tucket & $\begin{array}{l}\text { New } \\
\text { Orleans }\end{array}$ & $\begin{array}{l}\text { Phila- } \\
\text { delphia }\end{array}$ & $\begin{array}{l}\text { New } \\
\text { York }\end{array}$ & Denver & Monolulu & $\begin{array}{l}\text { Baton } \\
\text { Rouge } \\
\end{array}$ & $\begin{array}{r}\mathrm{N} \\
\text { Hampton } \mathrm{N} \\
\end{array}$ & $\begin{array}{l}\text { Newport } \\
\text { News }\end{array}$ & $\begin{array}{l}\text { Nash- } \\
\text { ville }\end{array}$ & $\begin{array}{l}\text { Virginia } \\
\text { Beach }\end{array}$ & Chesapeake & $\begin{array}{l}\text { Jackson- } \\
\text { v1]le }\end{array}$ & $\begin{array}{l}\text { Carson } \\
\text { City }\end{array}$ & $\begin{array}{l}\text { Indian- } \\
\text { apolis }\end{array}$ & Juneau & Colurhus \\
\hline $\begin{array}{l}\text { Year of } \\
\text { Consolidation }\end{array}$ & 1695 & 1805 & $\begin{array}{r}1854 / \\
1949\end{array}$ & 1898 & 1901 & 1907 & 1949 & 1950 & 1958 & 1962 & 1963 & 1963 & 1968 & 1962 & 1970 & 1970 & 1971 \\
\hline $\begin{array}{l}\text { Population } \\
\text { C1ty-County } \\
\text { SN.SA (1000s) }\end{array}$ & $\begin{array}{l}4 \\
\text { NA } 7\end{array}$ & $\begin{array}{r}586 \\
1,034\end{array}$ & $\begin{array}{l}1,927 \\
4.774\end{array}$ & $\begin{array}{r}7,720 \\
11.410\end{array}$ & $\begin{array}{r}513 \\
1,240\end{array}$ & $\begin{array}{l}3 \times 0 \\
629\end{array}$ & $\begin{array}{l}162 \\
2.85\end{array}$ & $\begin{array}{l}119 \\
28310\end{array}$ & $\begin{array}{l}137 \\
633\end{array}$ & $10 \quad \begin{array}{l}444 \\
58910\end{array}$ & $\begin{array}{l}160 \\
633\end{array}$ & $\begin{array}{r}89 \\
633\end{array}$ & $\begin{array}{l}513 \\
5 \div 9\end{array}$ & $\begin{array}{l}35 \\
\text { NA }\end{array}$ & $\begin{array}{r}743 \\
1.300\end{array}$ & $\begin{array}{l}13 \\
\text { NA }\end{array}$ & $\begin{array}{l}15 \% \\
232\end{array}$ \\
\hline Area $(\text { sq. m1. })^{1}$ & 1.8 & 205 & 129 & 300 & 68 & Bis & 31 & 55 & 69 & 527 & 255 & 344 & 766 & 150 & 400 & 3.208 & 220 \\
\hline $\begin{array}{l}\text { Density }{ }^{3} \\
\text { City-County }\end{array}$ & 220 & 2,800 & $15,00 \mathrm{C}$ & 25,700 & 7,500 & 3,800 & $5,20 \mathrm{C}$ & $2,1<0$ & 1,950 & 842 & $65 i$ & 259 & 669 & 103 & 1.257 & 4 & 691 \\
\hline $\begin{array}{l}\text { Population } \\
\text { Change }-\not \\
(1960-1970)\end{array}$ & +42.9 & -6.7 & -4.3 & -0.9 & +4.3 & +8.2 & +6.6 & +33.7 & +20.2 & +159.6 & +95.3 & +20.3 & +155.2 & +199.6 & +56.1 & 0 & +30.0 \\
\hline Nedian Age ${ }^{z}$ & $n a^{8}$ & 30.2 & 33.4 & 35.1 & 31.2 & 26.2 & 25.3 & 25.6 & 25.1 & 28.7 & 23.0 & 24.6 & 30.6 & na & 30.2 & $n a$ & 25.3 \\
\hline Medjan Education ${ }^{2}$ & na & 9.0 & 9.6 & 10.1 & 12.1 & 12.1 & 11.9 & 11.8 & 10.7 & 8.9 & 12.0 & 9.6 & 9.5 & na & 10.8 & na & 9.8 \\
\hline $\begin{array}{l}\text { Proportion of } \\
\text { Population } \\
\text { Employed }\end{array}$ & na & .35 & .39 & .44 & .39 & .38 & .36 & .30 & .32 & .39 & .25 & .32 & .39 & na & .41 & na & .31 \\
\hline $\begin{array}{l}\text { Expense/Revenue } \\
\text { Ratio } 2,3\end{array}$ & na & 1.05 & 1.05 & 0.93 & 0.95 & 1.15 & 0.89 & $1.0 t^{\circ}$ & 1.04 & 1.22 & 1.00 & na & 1.42 & na & 0.93 & ne & 1.09 \\
\hline 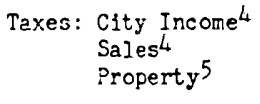 & $\begin{array}{r}\text { no } \\
\text { yes } \\
\text { na }\end{array}$ & $\begin{array}{r}\text { no } \\
\text { yes } \\
20\end{array}$ & $\begin{array}{l}\text { yes } \\
\text { yes } \\
98\end{array}$ & $\begin{array}{r}\text { yes } \\
\text { yes } \\
1,322\end{array}$ & $\begin{array}{r}\text { no } \\
\text { yes } \\
28\end{array}$ & $\begin{array}{r}\text { no } \\
\text { yes } \\
36\end{array}$ & $\begin{array}{r}\text { no } \\
\text { yes } \\
7\end{array}$ & $\begin{array}{r}\text { nn } \\
\text { yes } \\
6\end{array}$ & $\begin{array}{r}\text { no } \\
\text { yes } \\
8\end{array}$ & $\begin{array}{r}\text { no } \\
\text { yes } \\
39\end{array}$ & $\begin{array}{r}\text { no } \\
\text { yes } \\
5\end{array}$ & $\begin{array}{r}\text { no } \\
\text { yes } \\
\text { na }\end{array}$ & $\begin{array}{r}\text { no } \\
\text { yes } \\
6\end{array}$ & $\begin{array}{r}\text { no } \\
\text { yes } \\
\text { na }\end{array}$ & $\begin{array}{r}\text { no } \\
\text { yes } \\
29\end{array}$ & $\begin{array}{l}\text { no } \\
\text { no } \\
\text { na }\end{array}$ & $\begin{array}{r}\text { no } \\
\text { yes } \\
3\end{array}$ \\
\hline Originated by ${ }^{6}$ & Leg. & Leg. & 8 \& $/$ Vote 9 & Leg. & Leg. & Leg. & Vote & Vote & Vote & Vote & Vote & Vote & Leg. & Vote & Vote & Vote & Vote \\
\hline
\end{tabular}

1. 1970 preliminary flgures by Bureau of the Census. 2. Bureau of the Census, City and County Data Book 1967 (Washington, D.C., U.S. Governient Printing Office, 1957). 3. 1964-5 General Governiental Expenses/Gerieral Governmental Revenues. 4. Tax Foundation, City Income Taxes (New York, The Tax Foundation, 1970). 5. 1960 figures, 1n Pennsylvania legislature; Home Rule Act of 1949 which led to Consolidated Charter of 1951 . 10. 1960 areas of consolidating counties. 
cities.

As can be seen from Tables I and II, variables under consideration include (1) population, (2) density, (3) area, (4) population change over the period 1960-1970, (5) median age of the population, (6) median education of the population, (7) proportion of the population employed, (8) tax structure, (9) the general governmental expenses-to-revenues ratio, (10) age of the city at the time of change, (11) economic function, and (12) governmental structure.

In addition, the variables include the A.C.I.R.'s presence of a critical situation which requires remedial action (hereafter called an internal crisis), and the presence of a "red herring" situation (hereafter calied an external crisis) which arises after the initiation of the consolidation issue and tends to detract from the consoliation issue itself.

In order to test the possibility that some of these variables might be interrelated (for example, the larger the population, the greater the density or area, and perhaps the older ard less well-educated the members of the population), the cities were ranked low to high in terms of each of the 10 rankable variables (numbers 1 through 10), and a spearman Rho55 test applied to the results. Pable III, a portion of the overall 10-by-10 table, shows that the rankings all

55 spearman's Rho $==\left(6 \sum D^{2}\right) /\left(n\left(n^{2}-1\right)\right)$ where $D$ is the difference in ranking for one city on two variables, and $\mathrm{n}$ is the total number of cities. 
yield Rho in non-significant ranges. The exception was area and density (not shown, but with a Rho of -.97). This is, of course due to the relationship: Density = Population/ Area. As a consequence, area was dropped as a potential key variable, aue to its redundancy.

\section{TABLE III}

CORRELATION NATRIX - SPEARMAN RHO

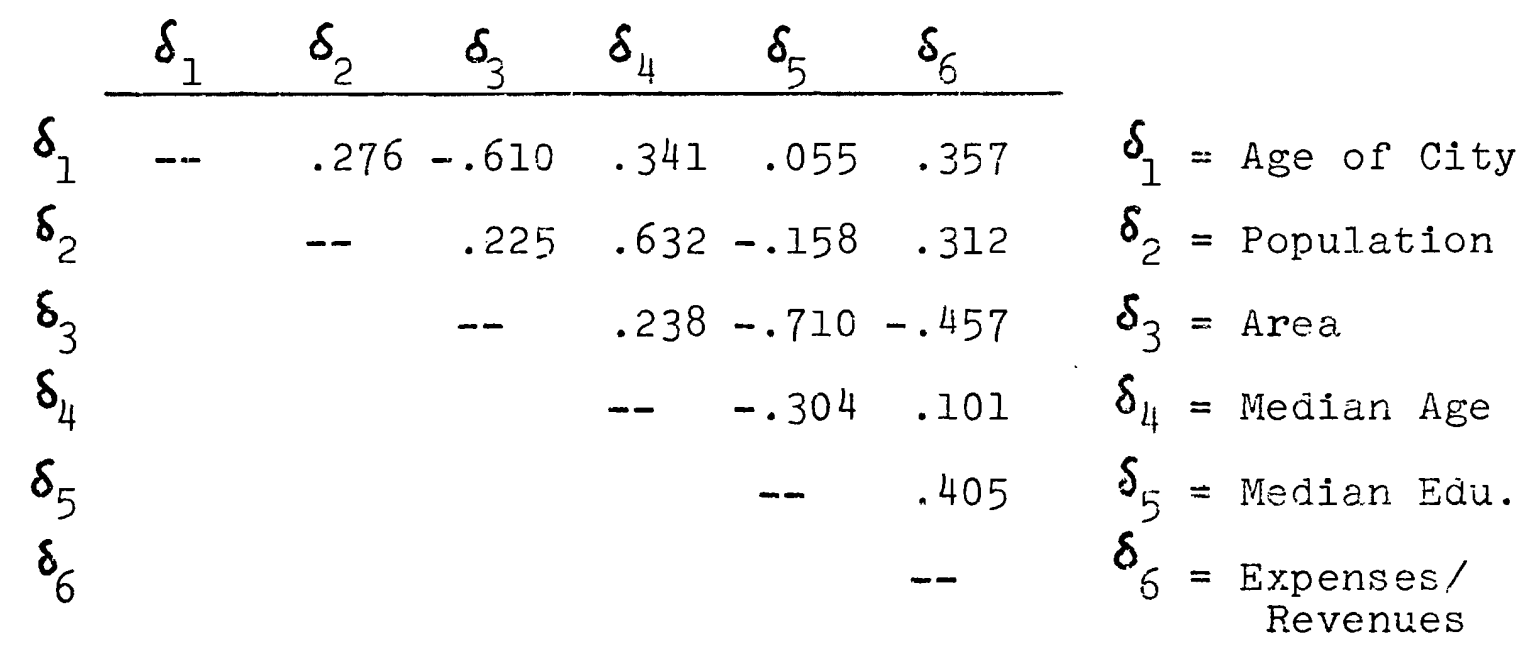

A series of product-moment statistics $\left(r_{x y}\right)$ was performed on a random sample of the 45 possibie intercorrelations of 10 variables taken two at a time. The $r_{x y}$ did not give nore than a 5\%-10\% variance from the Spearman Rho results in their respective measurements, thereby confirming the lack of intercorrelation of these variables.

As an indication of certain uniformities among consolidated units, it should be noted from the preceding tables that more than three-fourths of the consolidated governments are characterized by the mayor-council form of structure. 
There are variations to account for school systems, stateappointed independent departments, and so forth. Figure 2 illustrates the typical table of organization for consolidated units. Of course, the departmental breakdown is by no means meant to be anything more than a generalized representation, indicative of the typical structure.

After determining the general size and distribution of the consolidated units, a control group was chosen randomly within size and distribution parameters to control for those variables. The distribution of the control group approximates the distribution of the consolidated group, and the mean and median populations are equal if New York City's population of nearly 8 million is ignored for the purposes of establishing those parameters. A chi-squared test of the spatial distribution of the consolidated and control groups (by region: North, South, Central, and West as established by the Census Bureau) accepts the null hypothesis on the .05 level. Likewise, ignoring New York City's contribution56 to. the total population of the consolidated group, the populations of the consolidated and control groups are significantly similar on the .05 level.

56 It is, of course, dangerous to ignore or deliberately alter data collected in any study for the purposes of "making things come out right". There are, however, no cities of comparable size to which one could pair off New York in the United States. As a consequence, some statistics performed here are done both with and without New York's influence. In performing $T$ tests to determine differences in distribution means, both population size and population 


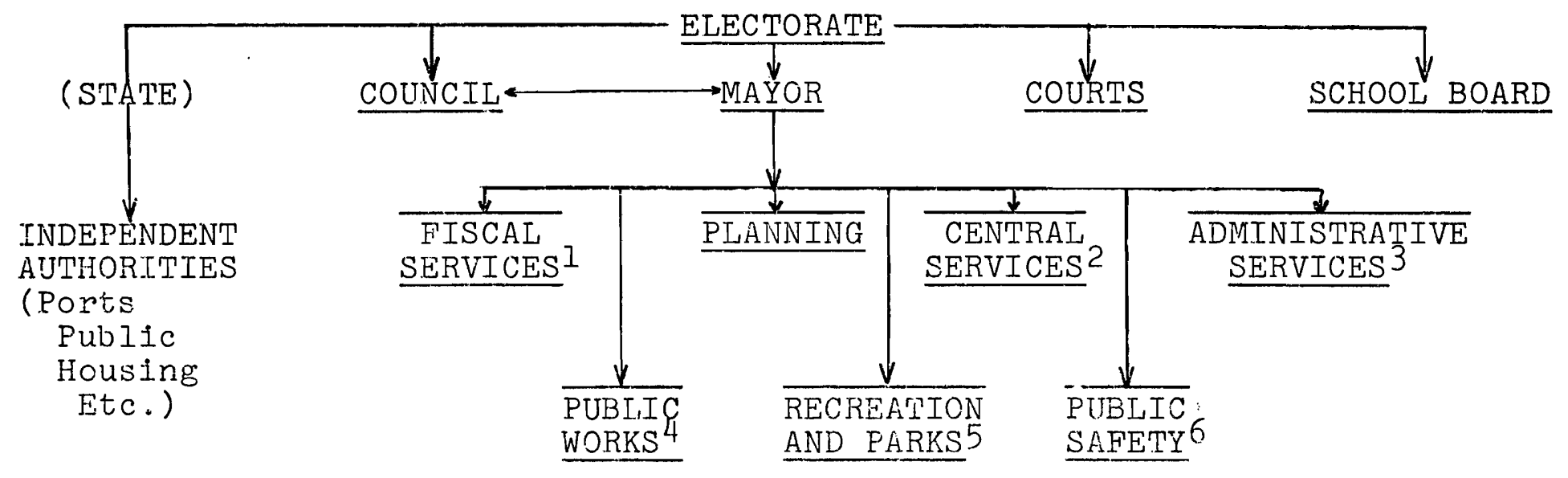

IIncludes Finance Department, Assessment, Collections, Accounting, and Budget.

2 Includes Personnel, Purchasing, Legal Services, Motor Pool, and Data Processing.

3Includes Administrative Officers, Advisory Boards and personal staff.

4 Includes Engineering, Streets and Highways, Garbage and Street Cleaning,

Building Maintenance, and Water and Sewer.

5 Includes Recreation Prograns, Parks, Libraries, and Public Service Projects.

Includes Police, Prisons and Jajls, Fire, and Civil Defense.

Figure 2. Typical table of consolidated governmental organization. 
The random control group chosen consists of the following cities: Atlanta, Georgia; Birmingham, Alabama; Cleveland, Ohio; Dallas, Texas; Des Moines, Iowa; Detroit, Michigan; East Hartford, Connecticut; Greenville, South Carolina; Hot Springs, Arkansas; Huntington, West Virginia; Lafayette, Louisiana; Lexington, Kentucky; Memphis, Tennessee; Phoenix, Arizona; San Jose, California; Tampa, Florida; and Union City, New Jersey. The same information as found in tables I and II were collected from the same sources for this control group, and the data is presented in table IV, page 39.

The generally-used arguments, both pro and con, are presented in table $V$. The opponents' arguments are used to provide the basis for determining the presence of an external crisis. Situations with primarily emotional impact which arise following the iaitiation of the consolidation issue, and which would detract from the rational, logical consideration of the strengths and weaknesses of consolidation are then defined to be external crises.

There is now a basis for comparison of the control and the consolidated groups. In the hopes of establishing significant differences between the two groups, the various variables isolated were compared under statistical tests. For those variables for which a mean and standard deviation

increase showed marked differences in the statistic with and without New York's influence. Whenever this has been done, it is so noted and both cases are presentea. 
TABLE IV

CONTROI GROUP DATA ${ }^{1}$

CITY

ATLAINTA, GA.

BIFMINGHAM, AY

CIEVELAND, OH

DAIILAS, TX.

DES MOINES, IA.

DETROIT, MI.

EAST HARIFORD, CT. 1783

GREINVILLE, S.C. 186

HOT SPRINGS, AK.

HUNIINGTON, W.V.

IAFAYETTE, IA.

LEXINGTON, KY.

MEMPHIS, TN.

PHOENIX, AR.

SAN! JOSE, CA.

TAMPA, FI.

UNION CITY, N.J. $1861 \quad \mathrm{M}$
YEAR ECO ${ }^{2}$ GOV'T3 POP. INC. FN. STRUC. 1970

POP. DENSTTY CHANGE

1845 T My-Ald. 487

3,600

$297 \quad 5,400$

73911,500

8362,700

$700 \quad 3,300$

$1856 \mathrm{TAg} \quad \mathrm{Mn}$

$\mathrm{Mn}$

$1,500 \quad 12,100$

M

$$
\text { My- }
$$

$\mathrm{M}$

$\mathrm{My}-\mathrm{C}$

57

9,400

612,700

$\mathrm{My}-\mathrm{C}$

35

3,200

73

5,700

$1836 \mathrm{TAg}$

$\mathrm{Mn}$

66

6,100

1832 TAg Ny-Comm 108

$1826 \mathrm{TAg} \quad \mathrm{My}-\mathrm{C} \quad 621$

5,200

3,900

$1881 \mathrm{MAg} \quad \mathrm{Mn}$

$580 \quad 2,300$

$1850 \mathrm{TAg}$

1885 TM My-Comm

4363,600

My-Comm

274

$56 \quad 40,200$

Comm
MEDIAN MEDIAN PROP. EXP./ TAX' AGE EDU. EMP. REV. SIM.

$29.3 \quad 10.5 \quad 0.41 \quad 1.27$ Yes $\begin{array}{llllll}4.6 & 29.4 & 10.1 & 0.37 & 0.89 & \text { Yes }\end{array}$ $\begin{array}{llllll}-4.2 & 31.2 & 9.6 & 0.37 & 1.06 & \text { No }\end{array}$ $\begin{array}{llllll}56.4 & 29.3 & 11.8 & 0.40 & 1.15 & \text { Yes }\end{array}$ $\begin{array}{llllll}17.4 & 30.1 & 12.1 & 0.42 & 0.95 & \text { Yes }\end{array}$ $\begin{array}{llllll}-9.7 & 33.7 & 10.0 & 0.37 & 0.86 & \text { No }\end{array}$ $\begin{array}{lllll}-8.6 & 33.0 & 9.6 & 0.45 & 1.07\end{array}$ Yes $\begin{array}{llllll}13.8 & 27.1 & 11.5 & 0.41 & 0.90 & \text { Yes }\end{array}$

$\begin{array}{llllll}-3.3 & 40.1 & 9.8 & 0.36 & 1.15 & \text { Yes }\end{array}$ $\begin{array}{llllll}-3.2 & 32.9 & 10.7 & 0.36 & 1.05 & \text { Yes }\end{array}$ $\begin{array}{llllll}20.4 & 24.2 & 8.9 & 0.36 & 0.93 & \text { Yes }\end{array}$ $\begin{array}{llllll}13.1 & 28.4 & 9.8 & 0.38 & 0.96 & \text { Yes }\end{array}$ $\begin{array}{llllll}25.6 & 28.1 & 10.5 & 0.37 & 1.06 & \text { Yes }\end{array}$ $\begin{array}{llllll}34.1 & 28.4 & 11.8 & 0.37 & 1.03 & \text { Yes }\end{array}$ $\begin{array}{llllll}114.2 & 26.5 & 12.1 & 0.36 & 1.11 & \text { Yes }\end{array}$ $\begin{array}{llllll}120.0 & 32.2 & 10.2 & 0.37 & 1.37 & \text { Yes }\end{array}$ 1. Bymbols as in lables I and II. 2. Manufacturing, To = Tourism. 3. Ald = Board of Aldermen, Comm = Commission. 4 . Tax structure similar to consolidated group"s. 


\section{TABLE V}

\section{STRENGTHS AND WEAKNESSES OF CITY-COUNTY CONSOLIDATION}

\section{STRENGTHS AND EXPECTATIONS BY PROPONENTS}

1. Provides base for unified, coordinated program of services

2. Increases visibility of responsible agencies and individuals

3. Economies of administration and scale

4. Adjusts political boundaries to geographic ones

5. One government responsible to all

6. Efficiency through elimination of duplication of services

7. Elimination of intergovernmental conflicts

8. Fiscal equity through taxing districts

9. Spreads needed services - more for the money

10. Broadens tax base of the government providing the services

11. Eliminates outmoded and inadequate government structures

12. Combines city and county resources

13. Conveniences to individuals in receiving and using government services
WEAKNESSES AND EXPECTATIONS BY OPPONENTS

1. Iimited in handling multi-county problems

2. Lack of constitutional/legislative groundworls

3. Needs separate voting majorities

4. Resistance from those in office

5. Inflexibility of boundaries

6. More difficult to vary services by local areas and needs

7. Tax inequities

8. Proliferation of personnel, staff

9. Imposition of "big-brother government' on rural areas - spreads suburbs

10. Reduces local participation in local affajis

11. Raises legal questions over federal, state grants

12. Dilutes minority group voting strength

13. General inertia of population to drastic change 
could be determined, a T test for significant differences between the means was used (due to the population size involved, the mean can be considered approximately equal to the median through the normal distribution characteristics). For those variables involving a more qualitativ e aspect, the Chisquared test was used. The results of these tests are included in table VI.

As the table shows, consolidated city-counties have significantly higher populations (when New York is included), lower population densities, younger populations, a greater preponderance of the mayor-council or mayor-commission form of government and of finance and public administration as the city's major economic function, and greater amounts of rebated property taxes than do the cities of the control group. The remaining variables did not show significant differences between the consolidated and control groups.

The available histories of the control group cities' changes (particularly those with mayor-to-manager or commission types of changes) indicates that the A.C.I.R.'s conclusion that critical situations are related to major changes (such as consolidation) is upheld. 
TABLE VI

STATISTICAL TESTS OF VARIABLES

\begin{tabular}{|c|c|c|c|c|c|}
\hline VARIABLE & DESCRIPTION & CONSOLIDATED ${ }^{\dagger}$ & CONTROL 2 & \multicolumn{2}{|c|}{ STATISTIC AND LEVEL 3} \\
\hline$\delta_{1}$ & City age at change (yrs) & $97 \pm 72$ & $135 \div 61$ & $T=1.58$ & $p>.10$ \\
\hline$\delta_{2}$ & Economic Function & $\begin{array}{l}\text { Finance or } \\
\text { Pub. Aämin. }\end{array}$ & $\begin{array}{l}\text { Agr. } \\
\text { or } \\
\mathrm{Mfg}\end{array}$ & $x^{2}=16.30$ & $\mathrm{p}<.001^{4}$ \\
\hline$\delta_{3}$ & Government Structure & Mayor-Council & $\begin{array}{l}\text { Mayor-Bd } \\
\text { Comm. }\end{array}$ & $x^{2}=4.02$ & $p<.05$ \\
\hline$\delta_{4}$ & $\begin{array}{l}\text { Population change (\%) } \\
1960-1970\end{array}$ & $48 \pm 100$ & $25.4=38$ & $T=0.89$ & $p>\cdot 10$ \\
\hline$\delta_{5}$ & Median age (yrs) & $28.2 \pm .3 .5$ & $30.5 \pm 3.6$ & $\mathrm{~T}=1.98$ & $p<.05$ \\
\hline$\delta_{6}$ & Median education (yrs) & $10.5 \pm 1.2$ & $10.5 \pm 1.0$ & $T=0.00$ & $p>.10$ \\
\hline$\delta_{7}$ & Proportion employed & $0.38 \pm 0.05$ & $0.39 \pm 0.03$ & $T=0.67$ & $p>.10$ \\
\hline$\delta_{8}^{\prime}$ & $\begin{array}{l}\text { General governmental } \\
\text { Expenses/Revenues }\end{array}$ & $1.05 \pm 0.13$ & $1.05 \pm 0.13$ & $T=0.00$ & $p>.10$ \\
\hline$\delta_{9}$ & Population (thousands) & $\begin{array}{l}801 \pm 690^{5} \\
369 \pm 300^{5}\end{array}$ & $407 \pm 350$ & $\begin{array}{l}T=2.11 \\
T=0.34\end{array}$ & $p \leqslant .05$ \\
\hline$\delta_{10}$ & Density (people/sq. mi.) & $\begin{array}{l}4080 \pm 35005 \\
2724 \pm 2480^{6}\end{array}$ & $7347 \pm 4000$ & $\begin{array}{l}T=2.51 \\
T=4.02\end{array}$ & $\begin{array}{l}p<.05 \\
p<.001\end{array}$ \\
\hline$\delta_{11}$ & $\begin{aligned} \text { Taxes : } & \text { Sales } \\
& \text { City Income } \\
& \text { Rebated property } \\
& \text { (in millions) }\end{aligned}$ & $\begin{array}{c}\text { Yes } \\
\text { No } \\
123 \pm 116^{5} \\
23 \pm 175\end{array}$ & $\begin{array}{l}\text { Yes } \\
\text { No } \\
17 \pm 13\end{array}$ & $\begin{array}{l}\boldsymbol{x}^{\mathbf{2}}=0.05 \\
x^{2}=0.12 \\
T=3.31 \\
\frac{m}{1}=0.17\end{array}$ & $\begin{array}{l}p>.10 \\
p>.10 \\
p<.01 \\
p>10\end{array}$ \\
\hline
\end{tabular}

- TN $=17 . \quad Z_{N}=13.3$ standard $T$ test for significance of differences of means taken over whole population; level of significance set at $p=.05$ - computed levels indicated. 4Chi-squared by proportion method: I degree of Preedom. 5Figures reflect New Yorix City influence. 6Figures do not reflect New York City influence. 
CHAPTER IV

\section{SURVEY RESULTS}

\section{STATE, CONSOLIDATED, AND CONTROL GROUP RESULTS}

The primary survey of states was begun in December of 1970 and concluded in February of 1971 (officials contacted and techniques used are discussed on page 17). The design of the primary questionnaire was so structured as to determine (1) where the consolidated units exist; (2) the legal requirements in the state legal system for presentation of the consolidation question to a referendum; (3) the existence of potential consolidation attempts; and (4) the preserce or absence of approval of the consolidation concept at the state level. The results of this primary phase are listed in table VII, page 44, and these results are amplified upon by Appendix III.

As an aside to the first question, it should be noted that many of the state governments are unaware of functional consolidations that may exist within their boundaries. Two outstanding examples of this are Oregon and Wisconsin. Portland and Multnomah County, Oregon have consolidated their data processing departments, health departments, and 
TABLE VII

SURVEY RESULTS - STATES $(N=50) *$

NO NO RESPONSE
QUESTION:

\section{RESPONSE:}

I. Any city-county consolidated units in your state?

II. Is legislation required in your state for citycounty consolidation?

III. Is action currently under way to create city-county consolidated units in your state?

IV. Does your state officially favor the creation of city-county consolidated units?

V. Additional comments? 17

i. Legislation considered, passed, favored

ii. Not considered, passed, favored iii.studies under way

6
0 Functional

5-Functional only

9-Constitution 150 \& Amendments

1I-House \& Senate Bills

15-Yes but not listed

43

$I$

$16 \quad 21$

33

* See Appendix III for listings of states responding positively to questions I-III. 
their printing operations. 57 Milwaukee and Milwaukee County, Wisconsin have consolidated their sewer, water, park, and air pollution departments.58 other examples of a negative response to question I include Kansas and Washington, both states failing to list functional consolidations within their boundaries (Dodge City-Ford County's Police Records Division and Seattle-King County's Health Department). A listing of functionally consolidated city-courty units appears in table VIII on page 46.

Responses to the secondary survey (conducted between February, 1971 and May, 1971) were arranged on a proportiona.l basis to facilitate testing of differences by chi--squared. The control group was narrowed to include only those cities which have experienced some change in scope or structure since incorporating. The results of this enumeration, designed to test for legal, social, fiscal, and planning vitality and satisfaction in the operation of the changed government, are found in table IX on page 4 .

To further test for significant differences between the consolidated and control groups, the questions on the test instruments were scored and computed on the basis given in figure 3, page 48.

57 A. G. White, Portland-Multnomah County Consolidation - Chances for Success. Portland State University, Unpuolished Paper, 1970 .

58Herry J. Schmandt, Paul G. Steiribicker and George D. Wendell, The Milwaukee Metropolitan Study Commission. Bioomington, Indiana Univerísity Press, 1965. 
TABLE VIII

\section{FUNCTIONALLY CONSOLIDATED CITY-COUNTY UNITS}

\section{CITY}

\section{Atlanta}

Boise

Boston

Dodge City

Jonesboro

Iincoln

Milwaukee

Omaha

Eugene

Portland

Salt Iake C1ty

Seattle

Sioux Falls

\section{COUNTY}

\section{Fulton}

Ada

Suffolk

Ford

Craighead

Lancaster

Milwaukee

\section{Douglas}

Isane

Multnomah

Salt Lake city
King
6th Planning
District*

STATE

Georgia

Idaho

Massachusetts

Kansas

Arkansas

Nebraska

Wis consin

Nebraska

Oregon

Oregon

Utah

Washington

South Dakota

\section{DEPARTMENII (S)}

SOURCE

OF DATA

\section{No Response}

No Resporse

Finance, Admin.

Police Records

Planning

Planning

Sewers, Parks,

Air Pollution

Control

Planning

Jail Facilities

Health, Data

Processing,

Printing

No Response

Health

Planning
State Survey

State Survey

City of Boston

Topeka Newspaper

State Survey

State Survey

Schmandt et al

State Survey

Eugene Newspaper

Ongoing Research

State Survey

State Survey

state Planning Agency

F Plaring Districts take place of Courty function throughout South Dakota. See South Dakota. South Dakota. Planning and Development Districts. Sioux Falls, State of South $\overline{\text { Dakota, N. D. }}$ 
TABLE IX

SURVEY RESULTS - CONSOLIDA'TED AND CONTROL

\section{QUESTION} CONSOLIDATED*

I. Legally a city?

$$
\text { YES }
$$

1.00

0.00

1.00
0.00

$x^{2}=0.00$
$p=.10$

II. Social problems ariser?

$\begin{array}{lllr}\text { YES } & 0.00 & 0.46 & x^{2}=8.98 \\ \text { NO } & 0.94 & 0.54 & \mathrm{p}<.01 \\ \text { NO RESPONSE } & 0.06 & 0.00 & \end{array}$

III. Had to raise taxes?

$\begin{array}{llll}\text { YES } & 0.65 & 0.92 & \chi^{2}=4.88 \\ \text { NO } & 0.35 & 0.00 & p<.05 \\ \text { NO RESPONSE } & 0.00 & 0.08 & \end{array}$

Institute service charges?

$\begin{array}{lllr}\text { YES } & 0.35 & 0.62 & X^{2}=3.40 \\ \text { NO } & 0.59 & 0.23 & \mathrm{p}<.10 \\ \text { NO RESPONSE } & 0.06 & 0.15 & \end{array}$

IV. Plan more effectively?

$\begin{array}{lllc}\text { YES } & 0.71 & 0.70 & x^{2}=0.63 \\ \text { NO } & 0.06 & 0.15 & \mathrm{p}>.10 \\ \text { NO RESPONSE } & 0.23 & 0.15 & \end{array}$

V. Recommend to others?

YES
NO
NO RESPONSE

$\begin{array}{llr}0.71 & 0.38 & \chi^{2}=7.70 \\ 0.00 & 0.38 & p<.01 \\ 0.29 & 0.24 & \end{array}$




\begin{tabular}{|c|c|c|c|c|c|}
\hline \multirow[b]{2}{*}{ Aspect } & \multirow[b]{2}{*}{ Question } & \multicolumn{4}{|c|}{ Responses } \\
\hline & & $\overline{\underline{Y e S}}$ & No & Response & $\underline{\mathrm{No}}$ \\
\hline Legal & $\begin{array}{l}\text { Municipality legally a } \\
\text { city? }\end{array}$ & +1 & & 0 & -1 \\
\hline Social & $\begin{array}{l}\text { Social problems arisen } \\
\text { since change? }\end{array}$ & -1 & & 0 & +1 \\
\hline Fiscal & Had to raise taxes? & $-1 / 2$ & & 0 & $+1 / 2$ \\
\hline & $\begin{array}{l}\text { Had to institute service } \\
\text { charges? }\end{array}$ & $-1 / 2$ & & 0 & $+1 / 2$ \\
\hline Planning & $\begin{array}{l}\text { Been able to plan more } \\
\text { effectively? }\end{array}$ & +1 & & 0 & -1 \\
\hline $\begin{array}{l}\text { Satis- } \\
\text { faction }\end{array}$ & Recommend to others? & +1 & & 0 & -1 \\
\hline
\end{tabular}

Figure 3. Scoring chart for comparison of test instruments.

If a municipality retained its legal status after a major change, was able to handle social, fiscal, and planning functions well (in the perception of the officials involved), and officials were willing to recommend their form of government to others, then these factors were taken to be positive. If the opposite held for a factor, then it was considered to be negative. Assignment of numerical values in this case is of no significance and is adopted merely for computational ease, since any numerical values would preserve the relative relationship between the two groups. The test instrument score, I, was then computed as: 59

$$
I_{j}=\sum_{i=1}^{6} a_{i} \quad j=1,2, \ldots . N
$$


The means and standard deviations were then computed for each group ( $N=17$ for the consolidated group, $N=13$ for the control. group). The range of possible scores is then -5 to +5 . The I score for the consolidated group is $3.1 \pm 1.4$ (a range of 1.7 to 4.5 ), and for the control group is $1.2 \pm 2.2$ (a range of -1.0 to 3.4). A $T$ test yields a $T$ of 2.79 , showing significant differences between the two groups at the .05 level.

II. THE F'AILURES: A KEY TO UNDERSTANDING

Since the turn of the century, when machinery was made available by state legislatures for referenda on city-county consolidation, a total of 28 attempts to consolidate have been defeated at the ballot box, with many more tabled and filed away in the various stages of the consolidation process. Table $\mathrm{x}$ lists the consolidation attempts rejected by referenda since 1921 (see page 50). It should be noted that the first ten rejections occurred prior to the first successful consolidation by referendum in Baton Rouge. Since that time, 18 rejections have occurred as opposed to 10 successes: a two-to-one ratio. It should also be noted that three

59 In a more sophisticated situation, the factors $a_{i}$ would be weighted to give the formula:

$$
I_{j}=\sum_{i=1}^{m} k_{i} a_{i} \quad j=I, 2, . . N
$$

with a total of $m$ variables and a weight $k_{i}$ assigned to each variable $a_{i}$ on the basis of relative importance of the variable. 
TABLE X

CONSOLIDATIONS REJECTED BY REFERENDA

\begin{tabular}{llll} 
CITY & COUNTY & STATE & DATE \\
Oakland & Alameda & California & 1921 \\
Butte & Silver Bow & Montana & 1924 \\
St. Louis & St. Louis & Missouri & 1926 \\
Portland & Multromah & Oregon & 1927 \\
Pittsburgh & Allegheny & Pennsylvania & 1929 \\
Several cities & Ravalli & Montana & 1932 \\
Macon & Bibb & Georgia & 1933 \\
Cleveland & Cuyahoga & Ohio & 1935 \\
Jacksonville & Duval & Florida & 1935 \\
Miami* & Dade & Florida & 1948 \\
Newport News** & Warwick & Virginia & 1950 \\
Miami & Dade & Florida & 1953 \\
Nashville** & Davidson & Tennessee & 1958 \\
Albuquerque & Bernalillo & New Mexico & 1959 \\
Knoxville & Knox & Tennessee & 1959 \\
Macon & Bibb & Georgia & 1960 \\
Durham & Durham & North Carolina & 1961 \\
Richmond & Henrico & Virginia & 1961 \\
Columbus** & Muscogee & Georgia & 1962 \\
Memphis & Shelby & Tennessee & 1962 \\
St. Louis & St. Louis & Missouri & 1952 \\
Chattanooga & Hamilton & Tennessee & 1964 \\
Tampa & Hillsborough & Florida & 1967 \\
Athens & Clarke & Georgia & 1969 \\
Roanoke & Roanoke & Virginia & 1969 \\
Winchester & Frederick & Virginia & 1970 \\
Charlottesville & Albemarle & Virginia & 1970 \\
Bristol & Washington & Virginia & 1970 \\
\hline
\end{tabular}

* Later successfully formed urban county-iederated system. * Later successfully consolidated.

of the failures since 1950 have resubmitued the issue to the voters and have successfully consolidated, and St. Louis, Missouri, Macon, Georgia and Miami, Florida have all tried twice to consolidate and were unsuccessful.

In an attempt to determine why these cities failed to 
consoliaate with the counties around them, a final phase of the study was undertaken to administer a questionnaire to city officials (maycr's office or individual familiar with the consolidation attempt) of cities in which a consolidation attempt had failed within the last 20 years. This limitation was imposed to make this sample parallel the sample of successful consolidations submitted to a referendum, and included the 17 defeated attempts since Miami's in 1953. Of the 17 questionnaires sent out (see Appendix II), only 6 were returned. The results of this phase of the survey are found in table XI.

As can be seen by examining table XI, an attempt was made to determine an estimate of the causes of defeat (the covering letters directed the questionnaires to individuals who were in government or involved in the consolidation morement at the time); the types of education programs administered; the opposition groups which arose to defeat the consolidation attempt; and the aspect of consolidation most opposed by the voters.

Certain recurrent themes appear in each consolidation defeat: refusal of leaders to back or maintain backing to the consolidation issue; a fear of higher taxes; a fear of being lost in a big, unwieldly government; public apathy; and in the South a fear on the part of blacks that their vote would be diluted in the overall balance of power (as indeed happened in Nashville and Jacksonville).

One other factor appears throughout these failures. 
TABLE XI

SURVEY RESULTS - REJECTED CONSOLIDATIONS

\begin{tabular}{|c|c|c|c|c|}
\hline CITY AND YEAR & CAUSES* & EDUCATION * * & OPPOSITION & MOST OBJECTED TO \\
\hline $\begin{array}{l}\text { Nashville } \\
\text { In. } 1958\end{array}$ & $\begin{array}{l}\text { Voter alienation } \\
\text { Loss or confidence } \\
\text { in leadership }\end{array}$ & $\begin{array}{l}\text { "Good gov't" } \\
\text { groups }\end{array}$ & $\begin{array}{l}\text { County Court, } \\
\text { Police, Fire- } \\
\text { men }\end{array}$ & $\begin{array}{l}\text { B.lg gorernment } \\
\text {-Highar taxes } \\
\text { Loss of localism }\end{array}$ \\
\hline $\begin{array}{c}\text { Alsuquerque, } \\
\text { N. M. } 1.959\end{array}$ & $\begin{array}{l}\text { Provincialism, Fear of } \\
\text { higher taxes, city } \\
\text { rule over county }\end{array}$ & $\begin{array}{l}\text { League of Women } \\
\text { Voters }\end{array}$ & $\begin{array}{l}\text { Flood control } \\
\text { "antagonists" }\end{array}$ & $\begin{array}{l}\text { Land use control } \\
\text { Loss of local } \\
\text { gov'tal jobs }\end{array}$ \\
\hline $\begin{array}{l}\text { Mempinis } \\
\text { Tn. } 1962\end{array}$ & $\begin{array}{l}\text { Racism } \\
\text { "Misunderstanding on } \\
\text { part of voters }\end{array}$ & $\begin{array}{l}\text { News media } \\
\text { Speaker programs }\end{array}$ & $\begin{array}{l}\text { Biacks, rural } \\
\text { politicians }\end{array}$ & $\begin{array}{l}\text { BIg government } \\
\text { Loss of localism }\end{array}$ \\
\hline $\begin{array}{l}\text { Athens, } \\
\text { Ca. } 1969\end{array}$ & $\begin{array}{l}\text { Lack of concurrent } \\
\text { majority } \\
\text { Public apathy }\end{array}$ & $\begin{array}{l}\text { Open hearings } \\
\text { News media } \\
\text { Charter mailed } \\
\text { to each voter }\end{array}$ & $\begin{array}{l}\text { Blacks, rura]. } \\
\text { politicians } \\
\text { tandholders }\end{array}$ & $\begin{array}{l}\text { Consolidation } \\
\text { concept } \\
\text { Loss of local } \\
\text { gov'tal jobs }\end{array}$ \\
\hline $\begin{array}{c}\text { Winchester, } \\
\text { Va. } 1969\end{array}$ & $\begin{array}{l}\text { Lack of leadership } \\
\text { Lack of "understand- } \\
\text { ing" of issue }\end{array}$ & $\begin{array}{l}\text { Open heartings } \\
\text { News media } \\
\text { Pamphlet to each } \\
\text { voter }\end{array}$ & $\begin{array}{l}\text { Rural leaders } \\
\text { Smaller towns } \\
\text { Taxpayer's } \\
\text { ass'n. }\end{array}$ & $\begin{array}{l}\text { Big government } \\
\text { Higher taxes } \\
\text { Consolidation } \\
\text { concept }\end{array}$ \\
\hline $\begin{array}{l}\text { Chattanooga, } \\
\text { In. } 1970\end{array}$ & $\begin{array}{l}\text { Reaction to taxation } \\
\text { pollcies } \\
\text { Racism }\end{array}$ & $\begin{array}{l}\text { News media } \\
\text { Leaflets tailored } \\
\text { to each area }\end{array}$ & $\begin{array}{l}\text { NAACP local } \\
\text { chapter } \\
\text { Small business } \\
\text { men }\end{array}$ & $\begin{array}{l}\text { Higher tares } \\
\text { Dilution of } \\
\text { mincrity vote }\end{array}$ \\
\hline
\end{tabular}

* In the opinions of the surveyed officials.

**Kinds of Programs, groups active in súucation during campaign. 
In four of the six cases examined, opponents of consolidation attempted to introduce an external crisis that would detract from the issue of consolidation. In Albuquerque, the issue of flood control and land use control arose to help defeat the consolidation measure - issues that are emotionally important to the people of the region. In Mempis, Athens, and Chattanooga the race issue (in particular, bussing and the mixing of the races) was used to cloud the voters' opinions when the time came to vote. In a like manner, the contention was made in all of these cases that taxes would rise rapidly following consolidation, effectively drowning out proponents who admitted that taxes would rise, but at a much lower rate than the opponents contended. It can therefore be concluded that such an external crisis constitutes a negative influence upon the success of any consolidation attempt. 


\section{CHAPTER V}

\section{TOWARD A MATHEMATICAL THEORY}

\section{THEORETICAL CONSIDERATIONS}

Several variables have been shown to yield significant differences between cities that are consolidated with the counties surrounding them and cities that have not performed such consolidations either through failure or through the seeking of alternate solutions to their problems. The city's economic function and governmental structure, the median age of the city's population, the total population and population density, portions of the local tax structure, the presence of an internal crisis that threatens the existence of prevailing order, and the presence (or absence) or external crises all seem to enter into the equation which determines success or failure for a consolidation attempt.

The task is then to construct such an equation, taking into account a total of $\mathrm{n}$ possible variables and the possible weights assigned to each variable. In a natural sense, some factors will carry more weight than others - population pressure or willingness to accept change by a younger population might outweigh the sophistication (or lack thereof) brought about by the types of people living in a city of a specific economic function. To handle this task, a series 
of definitions must first be introduced.

Definition 1: Positive variable: a variable which adds to, or enhances, the chances for success in a consolidation attempt as measured by its presence in the sliccessful consolidation attempts and in being significantly different from the control group. Examples of positive variables are: size of city, as indicated by population and density; economic function; governmental structure of the city; median age of the population; the city's tax structure and taxing pressure placed upon the individual as indicated by property taxes; and the presence of an internal crisis which threatens the vitality or order of the city, in which the citizens feel that a positive change is necessary to maintain such vitality and order.

Definition 2: Negative variable: a variable which, if present, detracts from the consolidation issue through obscuring facts or arousing emotional side-issues (the "red herring" technique). If the negative variable is not present, then individual opjnion is expressed through the media of letters to the editor, speaking at public forums, and so on and is not suppressed or out-shouted by more militant cpponents. In this manner, by not detracting from the clarity of the issue, a positive value is impiied. An example of a negative variable is the presence of an external crisis; either long-standing (race, bussing, etc.) or artificially created (land-use control opponents, political authorities 
who stand to be displaced attempting to block a successful referendum, etc.).

Definition 3: Probability measure: an association of a variable with a number between and possibly including 0 and 1 , so that if there are $n$ variables in a specific issue and $n$ numbers associated on a 1-to-l basis with the variables, then the sum of all the numbers will lie between and possibly including 0 and 1 . In mathematical terms, given a variable $X$ and a measure $p(X)$ (read "p of $X "$ ), then:

$$
p(X)=y \text { where } 0 \leq y \leq 1
$$

If there are $n$ variables $X_{1}, x_{2}$ and so on up to $x_{n}$ which relate to the issue, then the sum of the measures associated with the variables is:

$$
\begin{aligned}
& \sum_{i=1}^{n} p\left(x_{i}\right)=\sum_{i=1}^{n} y_{i} \text { where } \\
& \sum_{i=1}^{n} y_{i} \text { lies between } 0 \text { and } I \text { and } \\
& \sum_{i=1}^{n} y_{i} \text { means } y_{1}+y_{2}+\ldots .+y_{n}
\end{aligned}
$$

Definition 4: Probability of success: the sum of all the probability measures of the positive variables as defined in definition $1\left(\mathrm{p}^{+}\right)$plus the sum of all the probability measures of the negative variables as defined in derinition $2\left(p^{-}\right)$. The probability of success $P_{S}$ is:

$$
P_{\mathrm{S}}=\mathrm{p}^{+}+\mathrm{p}^{-} \text {where } \mathrm{P}_{\mathrm{S}}=0 \text { if } \mathrm{p}^{+}+\mathrm{p}^{-}<0
$$

with, of course, the restriction that 


$$
0 \leq P_{S} S_{1}
$$

Definition 5: Weighting factor: a constant $k_{i}$, empirically determined, associated with the variable $i$ which gives the variable greater, equal, or lesser influence than the other variables in determining the probability of success in a consolidation attempt. The constants $k_{\dot{I}}$ are strictily between 0 and 1 , and the sum of all of the $k_{i}(i=1,2, . ., n)$ is $l$ :

$$
\sum_{i=1}^{n} k_{i}=1 \quad 0<k_{i}<1
$$

Definition 6: The White Epsilon $\epsilon_{i}$ : for the purposes of this study, a variable which approximates the Kroneker delta60 which can take on only the values 0 and 1. If $\delta_{i}$ is the $i$ th variable for the consolidated group, and $\delta_{i}^{\prime}$ is the ith variabie for a test city under study (for example, if $\delta_{i}=$ median age of consolidated group's population, then $\delta_{i}^{\prime}=$ median age of the test city's population), then $\epsilon_{i}$ is defined as follows:

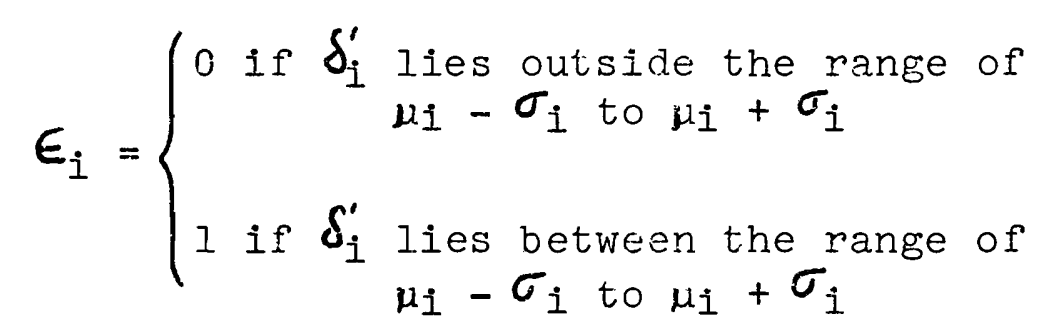

where $\mu_{i}$ is the mean of the ith variable $\delta_{i}$ associated with the consolidated group and $\sigma_{i}$ is one standard deviation of

$60_{\mathrm{Kroneker}}$ delta $\delta_{i j}=I$ if $i=j$ and $=0$ if $i \neq j$ in an $n X n$ matrix. 
the mean $u_{i}$.

Using the preceding definitions, the following formulations can now be made:

$$
\begin{aligned}
& p^{+}=\sum_{i=1}^{m} k_{i} \cdot \epsilon_{i} \\
& p^{-}=\sum_{i=m+1}^{n} k_{i} \cdot(-1)
\end{aligned}
$$

Equation 9 indicates that if the negative influence is present, then $a-k_{i}$ is contributed, and if the negative influence is not present, $a+k_{i}$ is contributed. From definition 4:

$$
P_{S}=p^{+}+p^{-}=\sum_{i=1}^{m} k_{i} \cdot \epsilon_{i}+\sum_{i=m+1}^{n} k_{i} \cdot(-1)^{\epsilon_{i}}
$$

where $n$ is the total number of variables, $m$ is the number of positive variables, and $(n-m)$ is the number of negative variables.

In the absence of a weighting scale, 61 which must be empirically determined, the $k_{i}$ must be taken to be of equal weight, so that:

$$
k_{1}=k_{2}=k_{3}=\cdot \cdot \cdot=k_{n}
$$

This reduces to:

$$
k_{i}=1 / n \text { for all } i=1,2, \ldots ., n
$$

and equation 10 then becomes:

$$
\dot{p}_{s}=\sum_{i=1}^{m} \frac{\epsilon_{i}}{n}+\sum_{i=m+1}^{n} \frac{(-1)}{n} \epsilon_{i}
$$

$6 I_{A s}$ this process calls for normative judgments by qualified personnel, the author respectfully declines to attempt to make such judgments. 
As a corollary to equation 13, by observing that the probability of an event can be at most l, then the probability of failure can readily be seen to be $1-P_{S}$, or:

$$
\mathrm{p}_{\mathrm{f}}=1-\left(\sum_{i=1}^{\mathrm{m}} \frac{\epsilon_{i}}{\mathrm{n}}+\sum_{i=m+1}^{\mathrm{n}} \frac{(-1)}{\mathrm{n}} \epsilon_{i}\right)
$$

It is now possible to test equation 13 against the empirical data found in tables I, II, and VII. Equatjng the variables listed in definition 1 with $\mathrm{p}^{+}$and the va: ble listed in definition 2 with $\mathrm{p}^{-}$, then $\mathrm{n}=8$. In thi: ase, the number of positive variables is 7 , and the number of negative variables is 1. Applying equation 13 to the data. collected for the consolidated cities and the defeated consolidation attempis, table XII can be constructed and analyzed.

If $P_{S}$ falls in the range of 0.50 to 0.70 , the results can be either success or failure. Below 0.50, failure appears to be certain (with the exceptions of Nantucket, which was legislatively consolidated, and Carson City, which was functionally consolidated). All cities with a $P_{S}$ above 0.70 were successfully consolidated.

of course, many variables are not considered here. Support by the news media, support by leadership, 62 the level of alienation felt by the voters, 63 and the composition and

62 ACIR, Factors Affecting Voter Reaction.

63E. I. McDil.I and J.C. Ridley, "Status, Anomia, Political Alienation, and Political Participation, "American Journal of Sociology (September 1962), pp. 205-213. 


\section{TABLE XII}

$$
\begin{gathered}
\text { RESULTS OF APPLICATION OF } \\
\text { PROBABILITY MEASURE } \\
P_{S}=\sum_{i=1}^{m} \frac{\epsilon_{i}}{n}+\sum_{i=m+1}^{n} \frac{(-I)}{n}
\end{gathered}
$$

\begin{tabular}{|c|c|c|c|}
\hline$\underline{\text { CITYY }}^{\text {SUCCESSFUL }}$ & $\underline{\text { PROBABILITY }}$ & $\begin{array}{l}\text { UNSUCCESSFUL } \\
\text { CITY }\end{array}$ & PROBABILITY \\
\hline (By Referenda) & & (By Referenda) & \\
\hline $\begin{array}{l}\text { Baton Rouge } \\
\text { Hampton } \\
\text { Newport News } \\
\text { Nashville } 1962 \\
\text { Virginia Beach } \\
\text { Chesapeake } \\
\text { Jacksonville } \\
\text { Carson City } \\
\text { Juneau } \\
\text { Columbus }\end{array}$ & $\begin{array}{l}0.88 \\
0.88 \\
1.00 \\
0.75 \\
0.75 \\
0.62 \\
0.75 \\
0.38 \\
0.50 \\
0.75\end{array}$ & $\begin{array}{l}\text { Athens, GA } \\
\text { Chattanooga, TN } \\
\text { Niemphis, TN } \\
\text { Nashvilie } 1958 \\
\text { Albuquerque, NM } \\
\text { Winchester, VA }\end{array}$ & $\begin{array}{l}0.38 \\
0.50 \\
0.50 \\
0.68 \\
0.38 \\
0.25\end{array}$ \\
\hline \multicolumn{4}{|l|}{ (By Legislature) } \\
\hline $\begin{array}{l}\text { Nantucket } \\
\text { New Orleans } \\
\text { Philadelphia } \\
\text { New York } \\
\text { Denver } \\
\text { Honolulu } \\
\text { Indianapolis }\end{array}$ & $\begin{array}{l}0.38 \\
0.88 \\
0.50 \\
0.50 \\
0.88 \\
0.88 \\
1.00\end{array}$ & & \\
\hline
\end{tabular}

predisposition of the charter commission members are just a few of the variables that would take several texts to determine quantitative scales for valid insertion into equation 13. (NOTE: At this point, the reacier is advised to refer to Appendix VI for definitions used in this section.) 
Assume that there are $\mathrm{n}$ possible variables which could affect the success or failure of an attempt of a city and county to consolidate. Also note that each of the variables listed in definitions 1 and 2 , and those that could possibly fit in those definitions, will vary in value over time. In order to introduce a short-hand notation, then:

$$
x_{I}=x_{1}(t), \cdot . \cdot, x_{n}=x_{n}(t)
$$

will mean that the variable $x_{i}(t), i=1,2, . . ., n$, varies over time $t$. As what is thought of as the "government of a city" develops over time, it aescribes a "path" in space and time which is called its world line. If it takes $n$ independent variables 64 to describe any given point on this path, then the path is called a curve in $\mathrm{n}+1$ - dimensional space, and this curve can be written in functional form as:

$$
\begin{aligned}
R & =f\left(x_{1}, x_{2}, \cdot \cdot, x_{n}\right) \\
& =f\left(x_{1}(t), x_{2}(t), \cdot \cdot, x_{n}(t)\right.
\end{aligned}
$$

where $R$ is the name of the curve representing the world line of a particular city, as determined by the $n$ independent variables. Here the variables could be manpower resource level, monetary resource level, legal flexibility, geographic flexibility, presence of crises, leadership and news media activity in governmental processes, and so forth.

If there are a total of $\mathrm{m}$ cities whose world lines are under scrutiny, then equation 16 may be written as:

${ }^{64}$ See Appendix VI for definitions and theory of mathematical concepts. 


$$
R_{j}=f_{j}^{\prime}\left(x_{1}, x_{2}, \ldots ., x_{n}\right) \quad j=1,2, \ldots, m
$$

The number $\mathrm{n}$ is taken to be the maximum number of variables necessary to describe the curve $R_{j}$, even though for a particular city it may take fewer than $n$ variables to describe its world line (the remaining variables are set equal to zero). Since the $n$ variables are those which are needed to determine the success or failure of a city-county consolidation attempt (or, with an expansion or contraction of $n$ to $n^{\prime}$, any governmental reorganization proposal), then $R_{j}$ car be thought of as some measure of the level of regional government in the metropolitan area under consideration. Each of the $n$ variables $x_{i}(t)$ can be thought of as a vector (magnitude plus directior - see Appendix VI) at any given time t. Each of these vectors is trying to "pull" the world line $R_{j}$ in a particular direction, and the resultant of these vectors determines in what direction $R_{j}$ is headed at tre time $t$. Moreover, if the number of dimensions required to describe $R_{j}$ is greater than three, it is impossible to intuitively view what the curve looks like or in which direction it is headed. It is possible, however, to observe what the projection (See appendix VI) of the curve $R_{j}$ looks like in the two-dimensional plane of a piece of paper, as shown in figure 4: 


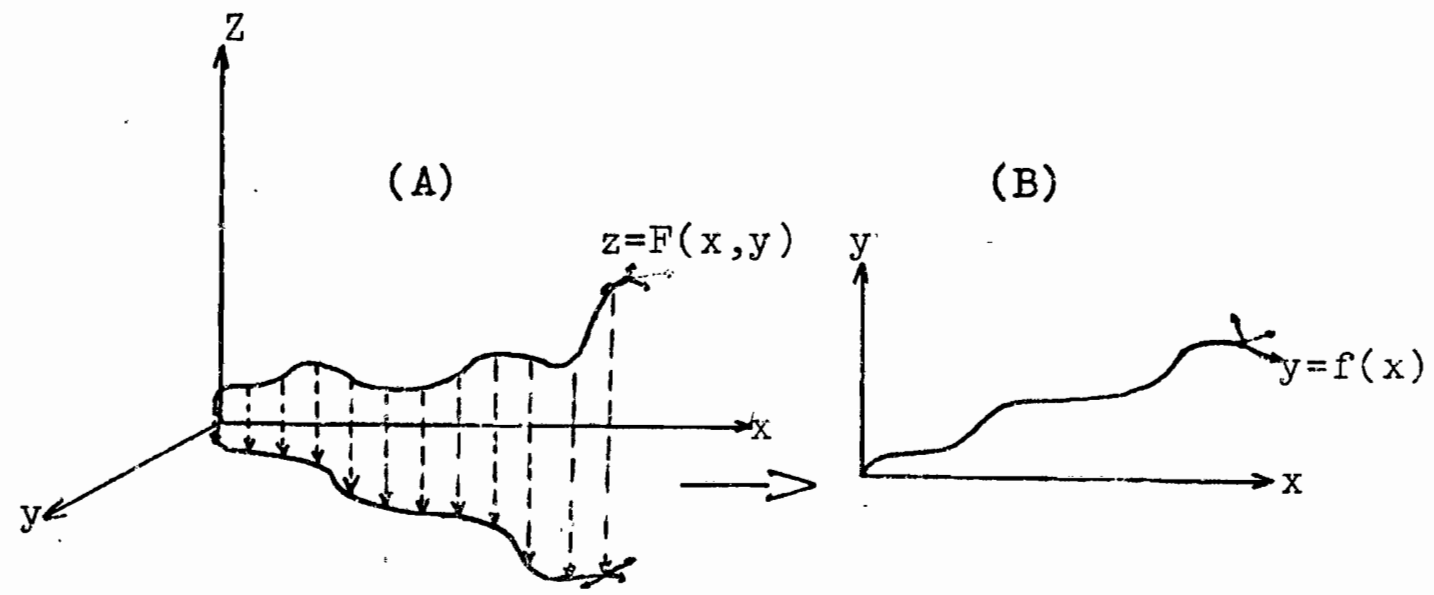

Figure 4. Projection of three-dimensional clirve (A) into the two-dimensional plane (B).

Instead of projecting a three-dimensional curve into a two-dimerisional one as in figures $4 \mathrm{a}$ and $4 \mathrm{~b}$, the projection process will involve projecting an $n+l$ - dimensional curve into a two-dimensional one. Then the function $R_{j}$, which represents the interaction of all $\mathrm{n}$ independent variables to determine the regional level of urban government, might appear as in figure 5:

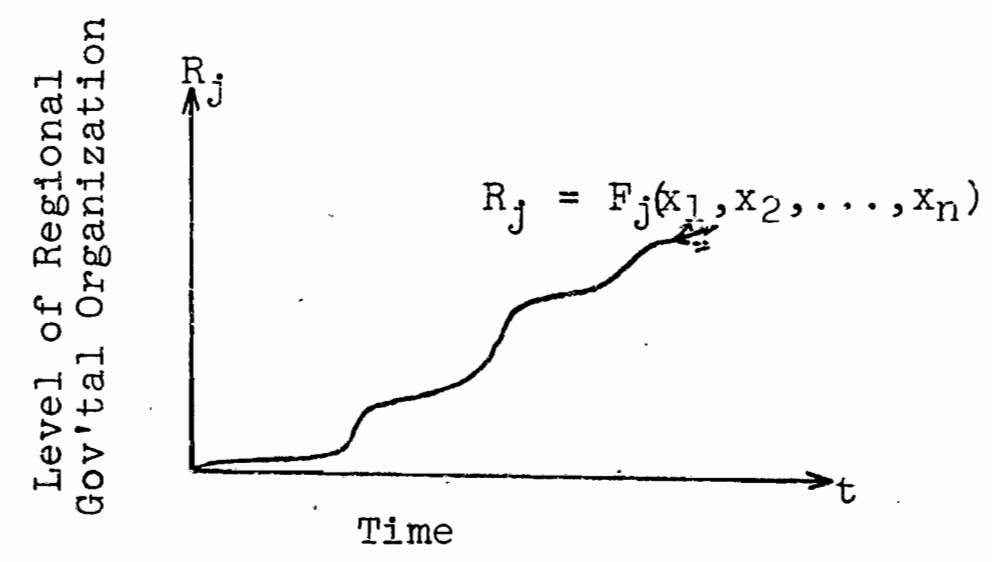

Figure 5. Projection of the function $R_{j}$ into the twodimensional plane: 
The time axis $t$ is used to show the relationship of the $\mathrm{n}$ variables to time, and the origin corresponds to time $t=0$, when the city under study was first incorporated. In this manner, it is possible to compare two or more cities on the same graph.

From the very nature and size of metropolitan governments, it can be intuitively seen that there is a great deal of inertia which must be overcome in accomplishing metropolitan reorganization. Money must be authorized, studies made by committees and accountants, enabling legislation enacted, opponents heard from, elections arranged, and so forth. A city is trappea at a certain level of organization until a set of circumstances arises to jog the city out of one level and into another (a drastic change in the resultant of the $n$ variables). To the end of describing these levels of organization, a relationship is postulated between $R_{j}$ and $t$ (level of regional government versus time) that might set forth a set of standardizea curves representing the levels that might be attained. Figure 6 shows one possible standaraized graph of regional organizational level anà $t$, and gives some of the levels L that a city and county can form in terms of regional organization: 


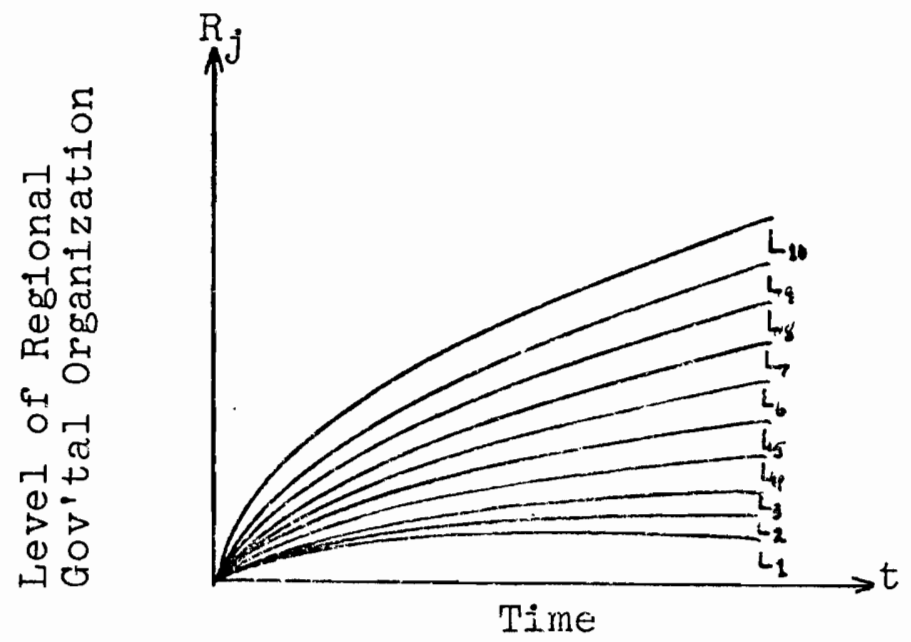

Figure 6. Standardized graph of levels of regional organjzation.

where $I_{1}$ represents no intergovernmental contacts; $L_{2}$ is intergovernmental cooperation (formal or informal); $\mathrm{L}_{3}$ is contracting for services; $\mathrm{L}_{4}$ is extraterritoriality; $\mathrm{L}_{5}$ is functional consolidation; $\mathrm{L}_{6}$ is the urban county; $\mathrm{L}_{7}$ is partial consolidation; $L_{8}$ is the level of merger; $L_{9}$ is the level of city-county consolidation; $L_{10}$ represents the level of federation; and the area above $L_{10}$ is left for future city-county regional agreement-types. Of course, other arrarigements and numbers of levels are possible. This is presented as merely one of a large number of possible schemes. Note that $L_{1}$ pertains not only to the city-annexes-parts of the county relationship, but to city-county separation as well. A natural restriction to place on the width of the bands (levels) is that they be strictly increasing, so that if $t_{2}-t_{1}$ is greater than 0 , then $W_{2}\left(L_{i}\right)-W_{I}\left(L_{i}\right)$ is greater than 0 , where $W$ is the width 
function of any level. $L_{j}$. This corresponds to the inertia concept - the longer an organization is "set in its ways," the harder it is to achieve any degree of change.

Combining the concepts of figures 5 and 6 , figure 7 represents the world line curves $R_{1}$ and $R_{2}$ for Hampton, Virginia and Carson City, Nevada respectively:

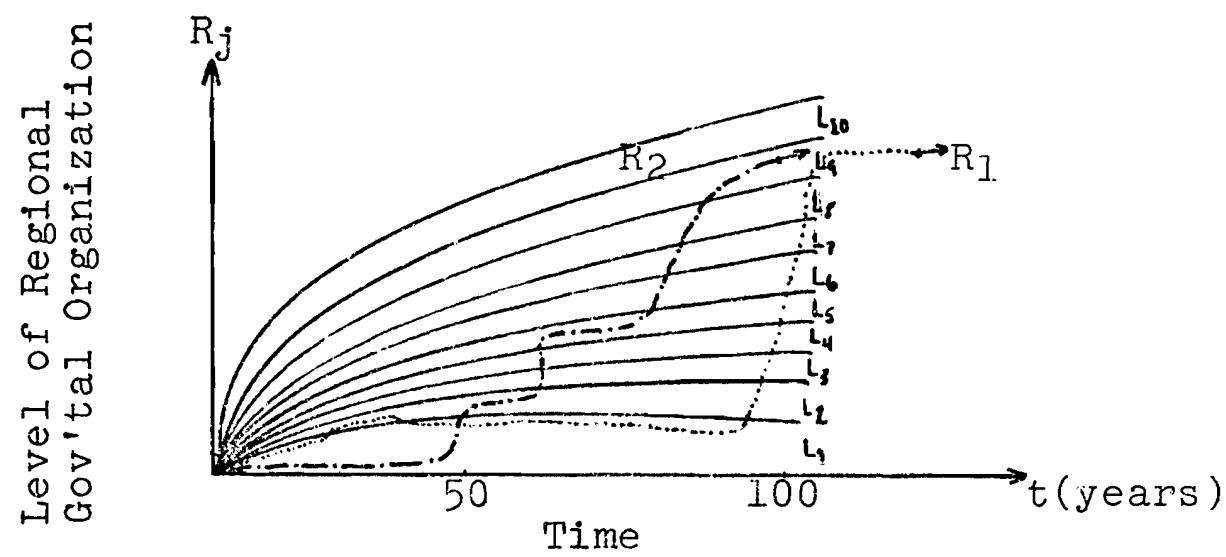

Figure 7. World line curves for Hamptor, Virginia and Carson City, Nevada.

It should also be noted that this representation allows for cities and counties to be created consolidated, as was the case with New Orleans and Honoluiu.

To briefly summarize this section, equation 13 yieids positive results in relating several variables to determine the probability of success or failure in an attempt of a city and county to consolidate. Equation 18, along with the use of a potential standardized graph, gives a possible mathematical/geometric model that, with knowledge of the values of the $\mathrm{n}$ independent variables involved, could 
determine the direction that the curve $R_{j}$ of a city's world line is heading. Both models can offer predictive measures of success or failure in a consolidation attempt.

\section{A TEST OF THE THEORY}

The city of Portland, Oregon unsuccessfully attempted to consolidate by referendum with Multnomah County in 1927. The League of Women Voters lists two other attempts in the 1930s which did not get as far as the ballot box.65

In the late 1950s and through the 1960s, Portland experienced the same difficulties as most other metropolitan areas throughout the nation - racial strife, rising costs of government, the declining purchasing power of its revenues, and a citizenry whose ability and inclination to subject themselves to additional taxation diminished rapidly. It was not until 1.966 that MuItnomah County voted to accept home rule, 65 which would permit its voters to consider consolidation as a solution to metropolitar problems.

The Oregon State Legislature submitted to a 1968 statewide referendum a constitutional amendnent permitting the formation of city-county consolidated units. The amendment was passed by a comfortable margin. 67 This amendment, plus

65 Ieague of Women Voters, City-County Consolidation, p. 3 .

66multnomah County, Home Rule Charter, Multnomah County: Oregor (Portland, Multinomah Courity, loob).

ofstate of Cregon, Oregon Blue Book - 1971-1972 (Salem, state of Oregon, 1971 ). 
enabling legislation passed in 1971 which created a commission to draw up a consolidated charter, would permit Muitnomah County (the smallest county in the state) and Portland (the largest city in the state) to vote on acceptance of a consolidated city-county charter.

Portland and Multnomah County have shown a willingness in the past to seek economies through consolidation. In the 1960 s, the health departments and the data processing departments of both governments were consolidated into citycounty departments. 68 A great deal of cooperative purchasing takes place, and plans are under consideration to consolidate portions of the police records division and the public works departiments. 69

Under the assumption that such a charter will be avajlable to vote on in November of 1974 (the charte: commission is given two years to devise a charter), the following data is presented for analysis in equation 13:

$$
\begin{aligned}
& \delta_{1}=\text { Economic function }=w T \quad \epsilon_{1}=+1 ; \frac{\epsilon_{1}}{8}=1 / 8 \\
& \delta_{2}=\begin{array}{r}
\text { Population }=\text { City }-375,000 \\
\text { City-County }-556,000
\end{array} \\
& \epsilon_{2}=+1 ; \frac{\epsilon_{2}}{8}=1 / 8 \\
& \delta_{3}=\begin{array}{l}
\text { Density }=\text { City }-5600 \\
\text { City-County }-1220
\end{array} \quad \epsilon_{3}=+1 ; \frac{\epsilon_{3}}{8}=1 / 8
\end{aligned}
$$

68Lybrand, Ross Brothers, and Montgomery, Program for Combining EDP Systems (Portland, Lybrand, Ross Brothers, and Montgomery, 1965$)$.

69"City, County Agencies to Start Consolidation," The Oregonian, Nay 19, 1971 . 


$$
\begin{aligned}
& \begin{array}{c}
\delta_{4}=\text { Meaiar age of population } \\
=36.7
\end{array} \\
& \delta_{5}=\begin{array}{c}
\text { Governmental structure } \\
=\text { Mayor-Council }
\end{array} \\
& \delta_{6}=\begin{array}{c}
\text { Tax structure }=\text { No sales, } \\
\text { No income, Rebated } \\
\text { property }=19.5 \text { million }
\end{array} \\
& \epsilon_{5}=+1 ; \frac{\epsilon_{5}}{8}=1 / 8 ; \frac{\epsilon_{6}}{8}=1 / 8 \\
& \delta_{7}=\text { Presence of an internal crisis }=? \\
& \delta_{8}=\text { Presence of an external crisis }=?
\end{aligned}
$$

Since there is no way to know what $\delta_{7}$ and $\delta_{8}$ will be until the time of the referendum, all of the possible combinations listed in table XIII must be considered.

\section{TABLE XIII}

POSSIBLE CRISES OUTCONES

Internal Crisis

YES NO

$$
\epsilon=+1 \quad \epsilon=0
$$

ExternaI

Crjisis

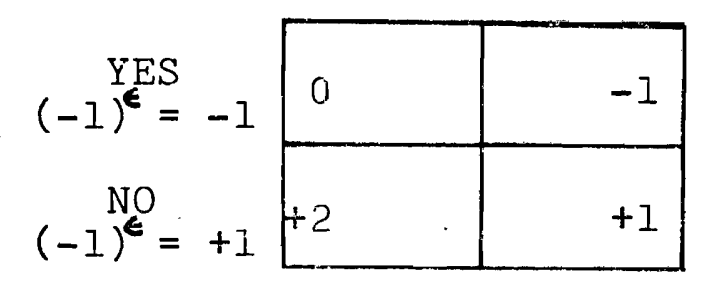

Considering these possibilities in their fractional forms, then $P_{S}$ for Portiand is:

$$
P_{S}=5 / 8+\left\{\begin{array}{l}
-1 / 8 \\
0 \\
1 / 8 \\
2 / 8
\end{array}=\left\{\begin{array}{l}
4 / 8=0.50 \\
5 / 8=0.62 \\
6 / 8=0.75 \\
7 / 8=0.88
\end{array}\right.\right.
$$


Using the interpretations of the previous section, it can be readily seen that if there exists an external crisis at the time of the referendum for the consolidated charter, which would detract from the consolidation issue, then Portland-Multnomah County's chances for consolidation fall into the "maybe" range of 0.50 to 0.70 . If no external crisis arises, then the chances of successful consolidation are increased to 0.75 or higher.

Assuming that these eight variables affect in some major way the world line $R$ of Portland, and assuming that ro major changes occur between the initiation of the Charter Commission in 1971 and the referendum on the consolidated charter in 1974, then a sketch of $R$ would appear as in figure 8:

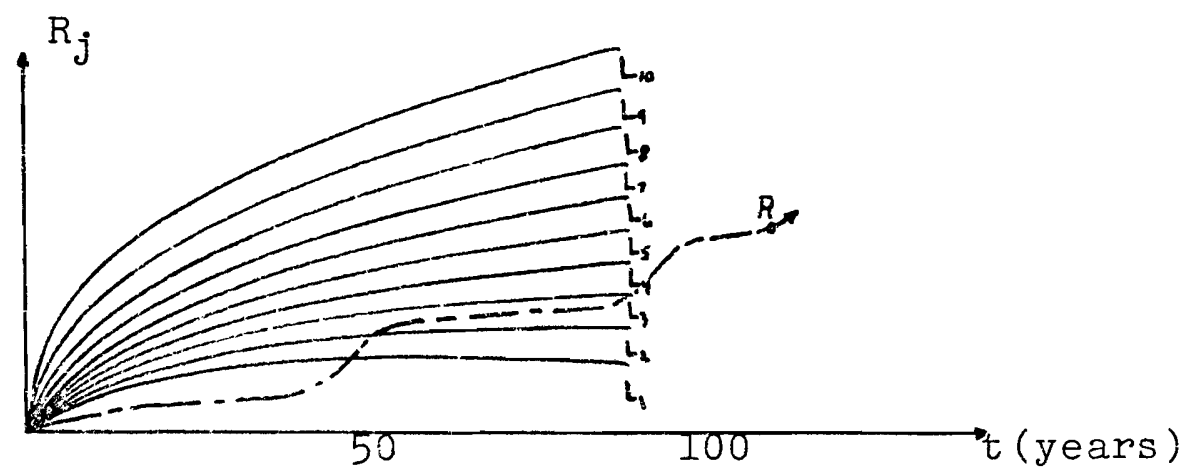

Figure 8. World curve for Portland, Oregon.

As can be seen from the curve $R$, Portland did not involve Itself with other governments regionally until it was about 60 years old, when it started providing services under contract (water, sewage treatment, etc.). At age 110, 
Portland and Multnomah County consolidated their health departments, and a few years later consolidated their data processing units.

In assessing probabilities, no guarantees can ever be made. However, if whatever groups arise to support the consolidation measure in Portland can suppress any external crisis that may arise, and point out (or perhaps even create the impression of) internal crises, the probability of success for Portland and Multnomah County in their consolidation attempt would be greatly increased.

If, on the other hand, opposing groups can expose or create external crises and minimize internal ones, then the probability of success could be decreased or at least maintained in the range where doubt concerning the outcome is strong. 


\section{CHAPTER VI}

\section{CONCLUSIONS}

It is sometimes as difficult to come to clear, concise conclusions about research data as it is to devise clear, concise, ard testable hypotheses. The boundary between what is causal and what is effect can be very indistinct, and it can often be impossible to distinguish which is which.

This ambiguity can sometimes be reduced through roigorous use of the scientific method and statistical inference. The preceding portions of this study have demonstrated the use of the scientific method, and have developed the use of generally accepted statistical techniques on the gathered empirical data. It is now time to examine the hypotheses and the data together, in order to draw some conclusions. HYPOMHESIS 1 . "There exists significant differences of certain variables, to be empirically determined, between. city-county consolidated governments and other metropolitan governments which have sought alternative solutions to metropolitan problems." Table VI, page 42, lists six variables which show significant differences between the control and consolidated groups. The qualitative description of each consolidation (pages 20-29) indicates the presence of internal cmises which through their critical nature require 
remedial action (school disaccreditation, scandal among public officials, reactions to annexation policies - see pages 20 to 30$)$. An analysis of table XI indicates the presence of external crises in the cases of the consolidation failures (and not evident in the majority of successful cases), which detracted from the consolidation issue and confused (and perhaps reduced voter participation in) the reorganization measure under consideration. CONCLUSION: Hypothesis 1 is apparently confirmed.

The eight variables listed in the analysis of Hypothesis 1 then form the basis for the probabilistic model $P_{S}$ (equation 13). Equation 13 offers a good it to the data for both successes and failures in consolidation referenda. As more variables are isolated as being important to the consolidation process, the values of $\mathrm{P}_{\mathrm{S}}$ should provide a more refined forecast for future attempts at consoljdation.

The world line curve $R_{j}$ offers a model of regional organization as a function of the variables $x_{i}(t)$, and provides a visualization of world lines as a projection of $n$ variables into the two-dimensional plare. It should be possible for continued research to expand upon and clarify the concept of a city's approach to regional organization as a combination of the many variables acting upon and within a. city government.

HYPOTHESIS 2. "The vitality of a municipal corporation is retained or even strengthened under city-county 
consolidation." The definition and criteria for measurement of vitality are listed on page 8 .

(A) Certainly, city-county consolidated governments must perform all of the functions which the city and county did before it: indeed, it performs more functions than did either the city or county separately. It performs as a municipal corporation in most functions, and as a county for areas within itself which voted not to join the consolidation (for example, Jacksonville and Indianapolis).

(B) Viewed from the county level, the area, density, distribution and characteristics of the community's population remain basically unaltered, and as a municipal corporation the consolidated government, lessens the contrast between actual and optimum populations for the efficient and economical administration of the functions of (A) through elimination of costly duplication of services.

(C) The area which the municipal corporation embraces has in most cases been greatly enlarged, and all consolidated cities have retained the legal status of a city (see table IX and appendix III), including annexation powers and the ability to initiate future consolidations. Therefore, consolidated units are not forever frozen to the boundaries established upon consolidation (with the exception of such isiand cities as Honolulu and Nantucket), and could at some future date choose to continue exparision of city limits. (D) One of the major arguments for consolidation is 
increased visibility of the segments of government responsible for various services. The U. S. Department of Agriculture study of Nashville suburbanite roters (see footnote 27, page 13) inaicated a perception on the part of the voters of increaseu or at least stabilized satisfaction in the manner in which the metropolitan government was being run. The results listed in table IX also lend support to the view that consolidated governments can better meet the demands of urbanization and needs for more and expanded services.

(E) Many state programs (and federal programs) base decisions about amounts of money to be shared with urbar areas on population - the greatest good of the greatest number. Through consolidation, the popliation under the jurisdiction of the urban government usualiy shows a dramatic enough increase to warrant increased state and federal aid. With an increase in area and taxable property bases, consolidated governments enjoy a greater fiscal capacity in terms of the property and economic activities they may tax than that of unconsolidated muricipalities. Not ore of the consolidated cities nas had to impose a city income tax since those of Philadelphia and New York in the 1950s. Again, table IX shows that significantly fewer consolidated cities reportedly have had to raise taxes or impose service charges since consolidation than have those cities of the control group. CONCLUSION: Hypothesis 2 is apparently confirmed. HYPOTHESIS 3 . "In the views of the involved public 
officials, certain social control, fiscal, and planning functions are more easily performed under city-county consolidated governments than under metropolitan governments which have sought alternative solutions to metropolitan problems. Consequently, public officials of consolidated governments possess a more positive perception of their ability to deal with metropolitan problems than do public officials of metropolitan governments which have sought alternative solutions to metropolitan problems."

With respect to the functions listed in the first part of the hypothesis, the social control and fiscal functions (as they relate to the individual citizen) appear to be significantly more easily performed under the consolidated governments, in the views of the involved officials. On the other hand, no significant difference appears with respect to the planning function. Table IX and appendices IV and V enumerate the perceptual differences between public officials of consolidated governments and public officials of other metropolitan governments.

As for the second part of the hypothesis, this is indicated both by the responses to the function-performance questions and by the willingness of the public orficials to make recommendations about their form of government to other metropolitan governments. Of those officials of consolidated governments willing to make such a recommendation (12 of 17), all would reconmend city-county consolidation with 
varying degrees of enthusiasm and qualifications.

On the other hand, of those public officials in the control group cities, 6 of the 11 responding to the question were willing to recommend their form of metropolitan recrganization and 5 were willing to recommend against adoption of their form of metropolitan reorganization. If what these public officials are willing to put in writing is any reflection of the reality of the situation, then consolidated government officials as a whole do possess a more positive perception of their abilities to handle metropolitan problems than do public officials in the control group cities. CONCLUSION: Hypothesis 3 appears to be confirmed, with the exception trat no significant difference appears between the two grcups with respect to the planning function.

There is a question winch naturaily arises at this point: What do these conclusions mean? First of all, some cities are riper for city-county consolidation than others, depending on the city's governmental structure, the city's econonic function, and several other factors.

Second, the consolidated city-county is able to meet administrative and fiscal demands (as ref'lected by the city's revenue collections from its citizens) imposed upon it by its citizenry. In addition, it does so without the costly duplication and overlapping of departments most often found between cities and their adjacent counties.

Third, in the opinion of public officials, control of 
economic-social problems facing cities is more easily implemented under the expanded resources of the consolidated goverrments than under governments which have been reorganized in different manners. Additionally, there appears to be some greater degree of internal satisfaction with their governmental form on the part of those officials of consolidated units as opposed to officials of other metropolitan governments.

Finally, through the use of concepts from probability and mathematics, and based on the data collected and analyzed in this study, a predictive theory can be devised to account for past consolidation successes and failures as well as offering projected estimates for success in future consolidation attempts. As an application of this theory, the analysis of the up-coming consolidation attempt in Portlend and Multnomah County, Oregon rates the chances for success as fair to good, depending on the actions of key pro and con groups over the next two years.

Before concluding, it is perhaps useful to look at a representative image of the city-county consolidated unit a median of the seventeen cities that have approached their. metropolitan problems with the tool of a consolidated government. The city is for the most part in a single county. It has been 20 to 160 years since it incorporated as a city. It has a young population (median age betweer 25 and 30), whose education level is 10.5 years and whose employment 
level is between 35 and $40 \%$ of the overall population. The city as a whole stood to gain 40 to $50 \%$ in total population at the time of consolidation.

Folitically, the former city had (and has retained) the mayor-council structure of government, and consolidation took place through a referendum. There will be no indeperdent cities within the city-county's boundaries, but there will be one or perhaps two independent departments remaining as leftovers from the old governments - usually some part of the criminal justice system. There will have been some internal crisis at the time of consolidation which the positive vote resolved (or appeared to resolve), and there were no external crises which arose to detract from the consolidation issue (or if there were, they were successfully resolved or surpressed).

Fiscally, the city will have no city income tax, and the property tax will be about $\$ 200$ lower on a $\$ 25,000$ home than the national average. 70 As in most American cities, general local governmental expenses will exceed general loca. governmental revenues. As its major economic function, the city will be either a finance center or a public administration center.

of those groups supporting the consolidation issue, the most prominent will be the League of Women Voters, local

70 "Fising Taxes on Homes, and the Search for the Way Out," U. S. News and World Report, July 12, 1971, pp. 71-73. 
chambers of commerce, local "cosmopolitan" newspapers, and some city and county officials. Opponents will include smaller cities in the county to be consolidated, local "hometown" newspapers, rich suburbanites, farm bureaus and granges, and racial groups fearing a dilution of voting power. What is needed now is more research into the quantification of heretofore qualitative variables. It is not proposed that such things as human emotions, ideals, or aspirations can ever be scaled from one to ten and be totaliy depersonalized for computer processing. However, if urban governments are to survive, then the scientists who study these governments need to acquire all available data which could pertain to planning for needed changes, planning to rectify social ilis, and planning to chart the courses of world lines through the future. If it can be agreed upon at the national, state and local levels that the survival of the cities is desirable, then it is time for such research to begin. 


\section{A SELECTED BIBLIOGRAPHY}

A Future ior Nashville. Nashville: Community Services Committee for Daviason County and the City of Nashville, 1952 .

Adivisory Commission on Intergovernmental Relations. Urban America and the Federal System. Washington, D. C.: U. S. Government Printing Office, July 1961.

----, Governmental Structure, Organization, and Planning in Metropolitan Areas. Washington, D. C.: U. S. Government Printing Office, July 1961.

---- Alternative Approaches to Governmental Reorganization in Metropolitan Areas. Washington, D. C.: U. S. Government Printing Of fice, 1962 .

----, Factors Affecting Voter Reaction to Government Reorganization in Metropolitan Areas. Washington, D. C.: U. S. Government Printing office, 1962.

Adrian, Charles R. Governing Urban America. New York: McGraw-Hill, 1955.

Alaska, State of. Alaska Statutes: Title 29, Chapter 85, Sections 10-210. Juneau, Alaska: State of Alaska, N. D.

"Annexation vs. Consolidation." The Gresham Outlook. Apr. 29, 1971 .

"Annexations, Mergers Draw City Interest." Nation's Cities, Dec. 1959, p. 41.

"Anti-Mierger Tactics." The Oregonian. May 15, 1971..

"Anti-Metro Tactics." The Oregonian. Mar. 11, 1971.

Auble, Phillip M. "Major Issues Affecting City Government in 1971." Western City, Apr. 1971, p. 13.

"Backward Step." The Oregonian, Feb. 8, 1971.

Banfield, Edward C. and Wilson, James Q. City Politics. New York: N. Y., Random House, 1963.

Banfleld, Edward. "The Politics of Netropolitan Area Organization." Midwest Journal of Political Science. Vol. I, \#, May, 1957, pp. $72-91$. 
Barron, Richard L. Staff Report Concerning Planning Within the Tri-County Area. Unpublished paper, N. D. (mimeographed).

Baton Rouge, City of. Our City-Parish Government: A Thumbnail Sketch. Baton Rouge, Louisiana: City of Baton Rouge, N. D.

Beadce, Roy. "City Cost Ever-Rising, Club Told." The Oregon Journal. Mar. 32, 1971.

"Behind the City Council Campaigns." The Oregonian, Oct. 1, 1970 .

Berry, Brian J. L. and Meltzer, Jack. Goals for Urbar America. Englewood Cliffs, N.. J.: Prentice-Hall, 1967.

"Bills Signed - HB 1422." Oregon Journal. June 7, 1971.

Blair, George $S$. Analyzing Governmental Structure in a Metropolitan Area with Particular Reference to the Philadelphia Area, in Metropolitan Analysis. Philadelphia: University of Pennsylvania Fress, 1958.

"Blue-Ribbon Task." The Oregonian. Sep. 15, 1971.

"Board Approves Merger of City-County Bureaus." The Oregonian, Sep. 4, 1970.

Board of County Commissioners. Your Multnomah County Government Handbook. Portland: Multnomah County, Oregon, Jan., 1969 .

Bodine, Harry. "Consolidation Without Port Favored." The Oregonian. May 25, 1971.

----, "East County Fights Governmental Nierger." The Oregonian. June 17, 1971 .

----, "House, Senate Fail to Agree on 4 Bills." The Oregonian. June 8, 1971 .

---.-, "Port Inclusion in Merger Favored." The Oregonian. May 22, 1971.

Bollens, John C. and Schmandt, Henry J. The Metropolis: Its People, Politics, and Economic Life. NeW York, N. Y.: Harper and Row, 1965.

Bonelli. Editcrial Cartoon "Growing Up." The Oregon Journal. Apr. 15, 197I. 
Booth, David A. Netropolitics: The Nashvilie Consolidation. East Lansing, Michigan: Institute for Community Development, MSU, 1963.

Boston, City of. An Act to Provide for Regional Municipal Federations. Boston: City of Boston, 1970 .

-..--, An Act to Provide for Regional Municipal Federations. Boston: City of Boston, 1970 .

Bradfield, Irene. "Consolidation - Pitfalls, Factors in Success." The Press N.W. Niay 26, 1971.

-.-.-, "Consolidation: Heretical or Reasonable?" The Press N. W. Apr. 14, 1971 .

-.-., "A Look at Jacksonville." The Press N. W. May 19, 1971.

Braestrup, Peter. "Indianapolis Suburbanites Find Cause to Cheer Merger." The Washington Post. Sep. 8, 1970.

Bride, Edward. "City, Contractor Both Losers as Software Evades Perfection." Computerworld. Jan. 20, 1.971.

Brown, R. M. "The Urban Crisis." Greater Portland Commerce. Vol. 52, No. 36, Sep., 1966, pp. 32-35.

Bureau of Wunicipal Research and Service. Local Intergovernmental Cooperation in the Tri-County Area. Eugene, Oregon: University of Oregon, Nov., 1966.

Alternative Approaches to Government Reorganization in Metropolitan Areas: Report A-ll. Eugene, Oregon: University of Oregon, $1 \overline{962}$.

----, Factors Affecting Voter Reaction to Government Reorganization in Metropolitan Areas: Report M-15. Eugene, Oregon: University of Oregon, 1962.

Bureau of Public Administration. City Consolidation in the Lower Peninsula. Charlottesville, Virginia: University of Virginia, 1956.

Burgess, James V. "Consolidation in Georgia: Columbus and Muscogee County Merge Governments January 1." Nation's Cities. Dec., 1970, pp. 21, 27.

Cameron, J.F. "Consolidation Costs." - Letter to the Editor. The Oregonian. Jun. 12, 1971. 
Campbell, Don. "Unigov' in Indianapolis." Hartford, Connecticut Times. Feb., 1970.

Carson City, City of. Historical Data, Legal Requirements, Reasons and Effects of Consolidation of Carson City and Ormsby county into a New Entity - Carson City, Nevada. Carson City: City of Carson City, N. D.

Chambers, Cyril. "A Rural Voice in Consolidation." The Press N.W. Aug. 4, 1971.

Charter Commission for South Norfolk and Norfolk County, Virginia. Consolidation Agreement for the City of South Norfoik and Norfolk County, Virginia and Charter for the Consolidated City. South Norfolk and Norfolk County, N. D.

----, Shall We Push Together or Shall We Surrender Separately? South Norfolk and Norfolk County, Virginia, 1962.

-----, A Historic Past: A Promising Future. South Norfolk and Norfolk County, Virginia, $1 \overline{961 .}$

"Chattanooga Area Defeats Charter." National Civic Review. Vol. LIX, \#II, Dec., 1970. pp. 595-596.

Chattanooga Chamber of Commerce. Consolidated Government Charter. Chattanooga: City of Chattanooga, 1970 .

Chicago Home Rule Commission. Modernizing a City Government. Chicago: University of Chicago Press, I954.

"Cities Where Business is Best." U.S. News and World Report. Sep. 14, 1970, pp. 40-43.

"Cities Where Business is Best." U.S. News and World Report. Apr. 12, 1971, pp. 62-65.

City Council of Portland, Oregon. The Portland Handbook. Portiand, Oregon: Department, of Finance and Administration, 1969.

"City Council Prepares to Acquire Computers." The Oregonian. Jan. 20, 1971.

"City Council Votes to Submit Court Merger Plan to Voters." The Oregonian. Sep. 16, 1971.

"City, County Agencies to Start Consolidation." The Oregonian. May 19, 1971. 
"City-County Consolidation Approved in State Senate." The Oregonian. May 29, 1971.

"City-County Consolidation Measure Revised to Give Veto to Outskirts." The oregonian. May 20, 1971.

"City-Count,y Consolidation: '70's Trend?" Nation's Cities. Nov., $1969, \mathrm{pp} .26-33$.

City County Consolidation Task Force, PMSC. A Bill for an Act. Portland: Portland Metropolitan stūd Commission, Feb. 10, 1971 .

"City-County Cooperation Plan Tried." Topeka Daily Capital, Topeka, Kansas. Jan. 14, 1971.

"City-County Merger Bill Delayed." Oregon Journal. June 1, 1971 .

"City-County Merger Bill sent to McCall." The Oregonian. June 8, 1971.

"City-County Merger Given Nod." Oregon Journal. May 25, 1971.

"City-County Panel Planned." The Oregonian. Feb. 24, 1971.

"City-County Plan 'Cleaned Up' - Approval Indicated." The Oregonian. Apr. 15, 1971.

"Clty-County Plan Topic." The Oregonian. Aug. 31, 1971.

City Ircome Taxes. New York, N. Y.: The Tax Foundation, 1967.

"City Lines Would Fade." The Oregonian. Feb. 20, 1971.

"City Merger Bill Opposed." The Oregonian. Feb. 14, 1971.

Clausen, John A. and Ford, Robert N. "Controlling Bias in Mail Questionnaires." Journal of the American Statistical Association. \#42, 1947, pp. 497-511.

Columbian Research Institute. Fiscal Implications of Government Unification: Multnomah County. Portland, Oregon: Columbian Research Institute, March, 1969.

Columbus, Georgia, City of. Organization Chart for Columbus, Georgia Consolidated Government. Columbus, Georgia: City of Columbus, N. D.

Committee for Economic Development. Reshaping Government in Metropolitan Areas. New York: Committee for Economic Development, 1970. 
Committee on Urban Government: Local Government. Minutes of Hearings on HB 1054. Salem, Oregon State House, Mar. 2, 1971. (typewritten)

-.--, Minutes of Hearings on HB 1054. Salem, Oregon State House, Mar. 9, 1971. (typewritten.)

-.--, Minutes of Hearing on HB 1054. Salem, Oregon State House, Mar. 25, 1971. (typewritten.)

----, Minutes of Work Session. Salem, Oregon State House, Mar. 30, 1971. (typewritten.)

----, Minutes of Work Session. Salem, Oregon State House, Apr. 6, 1971. (typewritten.)

-...-, Minutes of Public Hearing. Salem, Oregon State House, Apr. 7, 1971. (typewritten.)

"Consolidation at Issue Agair." The Oregonian. Jan. 10, 1971.

"Consolidation Bill Approved by Senate." The Oregon Journal. May 29, 1971.

"Consolidation Bill Stalled." The Oregonian. June 1, 1971.

"Consolidation Challenge Fails." The Press N.W. Sep. 15, 1971 .

"Consolidation on Rails." The Oregonian. Apr. 15, 1971.

"Consolidation Suggested for Purchasing Facilities." The Oregonian. Feb. 13, 1971.

Cook, Vernon. "Fair Deal." - Letter to the Editor. The Oregonian. June 26, 1971.

----, "Consolidation." - Letter to the Editor. The Oregonian. May 19, 1971.

Coomer, James C. Nashville-Davidson County: A Study of Metropolitan Government. Nashville: American PoliticaI Science Association, 1969.

"Corbett's Stand on Consolidation." The Gresham Outlook. Mar. 25, 1971.

"Council Postpones Consolidation Move." Oregon Journal. Sep. 15, 1971. 
"Council Stalis Action on Court Consolidation." The Oregonian. Sep. 15, 1971.

"Council to Consider Resolution on City-County Tie." The Oregonian. Sep. 13, 1971.

"Council Wants Look at Court Merger Tag." The Oregonian. July 28, 1971.

"County Bill Wins Favor." The Oregonian. Apr. 2l, 1971.

"County Commissioners Fight Cook Amendment." The Oregonian. May 21, 1971.

"County Commissioners to Seek Merger Grant." The Oregonian. June 18, 1971.

"County Hits Amendments." Oregon JournaI. May 21, 1971.

"Court Consolidation Wins." The Oregonian. Mar. 31, 1971.

Dade County Manager's Office. A Status Report of Metropolitan Dade County, Florida. Dade County, Fir orida: Colinty Manager's Of'fice, Jan. 4, 1968.

-.--, The Home Rule Amendment and Charter. Dade County, Florida: County Manager"s of ice, ig69.

Facts and Figures 1970-1971. Dade County, Florida: County Manager's of fice, 1970.

"Day of Reminder." Jacksonville Journal. (Jacksonville, Florida.) October 1, 1970.

DeArnold, R. N. The Founding of Juneau. Juneau, Alaska: Gastineau Channel Centennial Association, 1967.

Denver Planning Office. Denver - 1969. Denver, Coiorado: Denver Planning Office, 1969.

Deweese, R. W. "Policies of the Portland Chamber of Commerce." Greater Portland Commerce Magazine. Vol. 53, \#5, February, 1969, p. 23.

Division of Local Government. Problems of Local Government. Denver, Colorado: State of Colorado, 1968 .

Dougias, Paul H. Building the American Cjty: Report of the National Committee on Urban Problems to the Congress and to the President or the Unitied States. Washington, D. C.: U. S. Government Printing Of fice, 1968. 
Dovell, J. E. City-County Consolidation: Its Possibilities in Florida. Gainsville, Florida: University of FIorida, 1956 .

Duncombe, Herbert Sydney. County Government in America. Washington, D. C.: National Association of Counties Research Foundation, 1966.

Durham Charter Commission. Report of the Durham CityCounty Charter Cormission. Durham, N. C.: Durham Charter Comission, 1960 .

"East County 'Rejects' Supercity." The Oregonian. Feb. 19, 1971 .

Eccles, David. "Eccles Proposes 10 year Tax Levy to Provide Funds for Open Spaces." The Oregonian. Jun. 25, 1970.

----, "City-County Link Eyes on Park Development." The Oregonian. Sep. 25, 1970 .

-..-, "Local Government is Incapable of Coping." The Oregonian. Jan. 4, 1970.

-----, "Urban County Coming." The Oregonian. Jan. 4, 1970.

Economic Research Service of the U. S. Department of Agriculture. Impact of City-County Consoiidation of the RuralUrban Fringe: Nashvilie-Davidson County, Tenriessee (Economic Report \#206). Washington, D. C.: U. S. Goverrment Printing Office, 1971.

Education Committee of the Committee on Consolidation. Facts About Consolidation. Winchester, Virginia: Committee on Consolidation, 1969.

Erickson, Steve. "Buck Grayson: I'm Not Going to Tell Them How to Run City Hail." The Oregonian. Jan. 3, 1971.

-..-, "Neil Goldschmidt: I'm Not Cut from the Same Mold as Sorne Members of the Council." The Oregonian. Jan. 3, 1971 .

Etter, Orval. The Metropolitan Borough: What Is It? Eugene: Report to the Portland Metropolit an Study Commission, January 1966.

Evans, Walter H. "Backs Court Merger." - Letter to the Editor. The Oregonian. July 15, 1971.

"5 Smali Cities Oppose Multnoman 'Supercity' Plan." Orezon Journal. Mar. 2, 1971. 
Gleason, M. James. "City, County Sign 20-Year Sewer Agreement." The Oregonian. Apr. 26, i968.

"Good Grade for Consolidation." Oregon Journal. June 17, 1971 .

Goodall, Leonard E. The Arrerican Metropolis. Columbus, Ohio: Charles E. Merril Company, 1.968.

Goode, R. Ray. Legislative Program: Memorandum. Dade County, Florida: County Manager's of fice, Oct. 20, 1970.

--.--, Legislative Report \#2. Dade County, Florida: County Manager's Office, Nov. 24, 1970.

----, Legislative Report \#3. Dade County, Florida: County Manager's Office, Dec. 1, 1971.

--- , Legislative Report \#4. Dade County, Florida: County Manager's Office, Dec. 8, 1970.

----, 1971 Legislative Program. Dade County, Florida: County Mianager's Office, Jan. 18, 1971.

---, 1971 Legislative Program. Dade County, Floriaa: County Manager's Office, Jan. 22, 1971.

Goranson, Eric. "East County Chiefs Hit Supercity." Oregon Journal. Feb. 19, 1971.

--.--, "Polka Dot' Metropolitan Fringe Suggested for Portland." Oregon Journal. Mar. 10, 1971.

Gordon, Mel. "Lobbyists and Local Government." The Press: City N.W. Dec. 2, 1970.

Grant, Daniel R. The States and the Urban Crisis. Englewood Cliffs, $\overline{\mathrm{N}}$. J.: Prentice $\overline{\text { Hall, } 1969 .}$

"Gresham Group Asks Consolidation Vote." The Press N.W. July $21,1971$.

Hauptman, Jerzy, Ed. The County and Intergovernmental Relations. Parksville, Missouri: Park College Governmental Research Bureau, 1968.

Havard, William C. and Corty, Floyd I. Rural-Urban Consolidation. Baton Rouge, Louisiana: Louisiana State University Press, 1964.

Hawkins, Brett $W$. Nashville Metro: The Politics of CityCounty Consolidation. Nashville, Tennessee: Vanderbilt University Press, 1966. 
Hays, Samuel P. "The Politics: Teform in Municipal Government in the Progressive Er." Pacific Northwest Quarterly. Vol. 55, \#4, October 1964. pp. $157-169$.

"Heartbreak and the Dawn." The Chattanooga Times. Aug. 7 , 1970 .

Hill, James. "City-County Consolidation High on List with Portland Candidates." The Oregonian. Oct. 25, 1970.

"Home Stretch for Merger Bill." Oregon Journal. May 31 , 1971.

Honolulu, City and County of. The City and County of Hono-

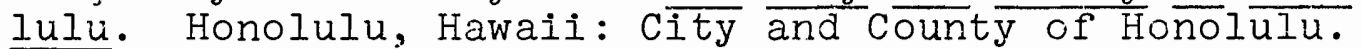
$\overline{\text { May, }} 1969$.

Horsley, Carter B. "Emphasis on Regional Approach Results in County Government Reforms." The Oregonian. Feb. 15, I.971.

"House Committee Limits City-County Consolidation Measure." The Oregonian. Apr. 8, 1971.

"House OKs Elimination of Portland City Courts." The Oregon Journal. May 29, 1971.

"House Republican Caucus Backs Bill to East City-County Merger." The Oregonian. Apr. 15, 1971.

"House Votes to Ax Court." The Oregonian. May 30, 1971.

H. U. D., State and Local Relations Division. State Urban Information and Technical Assistance Services - The

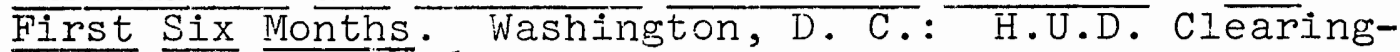
house Service, I969.

Hughes, Harold. "Political Headhunters Draw Bead on Council, Ignore Commission." The Oregonian. Dec. 21, 1969.

"Incorporation Attempt Fails." The Oregonian. Jun. 17, 1971.

Inaiana, State of. Consolidated Government for Indianapolis as Provided by Indiana State Bill 543. Indianapolis, Indiana: Indiana state Senate, N. D.

"Intergovernmental-Contractual Relationships in Washington." Western Cities. Apr., 1969. p. 22.

Interim Committee on Ürban Affairs. Urban Affairs and Mass Transportation. Salem, Oregon: State of Oregon, $1 \overline{970 .}$ 
"Intergovernmental Cooperation - Key to the Future." Kansas Government Journal. Vol. 54, \#4, Apr., 1968. pp. 155158.

Jacksonville, City of. October 1, 1968: A Date with Destiny. Jacks onville, Florida: City of Jacksonvilie, Oct. l, 1968.

----, News Release, no title. Jacksonville, Florida: City of Jacksonvilie, Oct. 1970.

-.-- News Release, no title. Jacksonville, Florida: City of Jacksonville, Nov. 18, 1970 .

----, A Better Place to Live Each Year. Jacksonville, Fiorida: City of Jacksonville, N. D.

"Jacksonville and Duval County, Florida to Merge." Nation's Cities. Sep., 1967. p. 30.

"Jacksonville Holds 'Largest City' Title Following Merger." Nation's Cities. Nov., 1968. p. 27.

"Jacksonvillians Like Consolidated City Government." The American City. Apr., 1970. pp. 79-81.

"Jail-Court Consolidation Hinges on Money Question." The Oregonian. Sep. 16, 1971.

Jerry, J. Michael. Jurisdictional Changes: Annexation and Consolidation: Report l. Madison, Wisconsin: State of Wisconsin. Jan., 1970 .

"Jobs For All?" U.S. News and World Report. Aug. 2, 1971. pp. $30-32$.

"Joker in Merger Bill." The Oregonian. Feb. 21, 1971.

Kansas, State of. Kansas Statutes Annotated, Chapter 12 , Article 29. Topeka, Kansas: State of Kansas, 19631970 Supplemental.

Kaplan, Harold. Urban Political Systems: A Functional Analysis of Metro Toronto. New York: Columbia University Press, 1967 .

Kean, R. Gordon Jr. The Baton Rouge Plan. Parish of Baton Rouge, Louisiana: City of Baton Rouge, N. D.

Keller, Bill. "Rival. Incorporation Plans Shatter Trarquility of Springdale." The Oregonian. May 30, 1971. 
Kentucky, state of. House Bill \#543. Louisville, Kentucky: Commonwealth of Kentucky General Assembly. Mar., 1970.

Kentucky Revised Statutes, Sections 67.190-.310 and $81.410-.440$. Louis ville, Kentucky: Commonwealth of Kentucky General Assembly, N. D.

Kessel, John H. "Governmental Structure and Political Environment: A Statistical Note About American Cities." American Political Science Review. Vol. LVI, \#3, Sep., 1962. pp. 615-620.

Kneier, Charles M. City Government in the United States. New York: Harper and Brothers, $\overline{19} 5 \overline{7}$.

Lawrence, David M. and Turnbull, H. Rutherford III. "Unigov: City-County Consolidation in Indianapolis." Popular Government. Nov., 1969, pp. 18-26.

Lawson, Bruce G. Merger and Consolidation of Local Government Units in the State or Oregon. Eugene, Oregon: University of Oregon, 1969.

"League of Arizona Cities and Towns Examines Intergovernmental Relations." Western City. Jul., 1969, pp. 19-22.

League of Oregon Cities. Proposed Oregon Municipal Policy. Salem, Oregon: League of Oregon Cities, 1970.

"Legislature Assists City-County Merger." The Oregonian. Feb. 28, 1971 .

Lent, Berkley; Hass, Harl; and Atiyeh, Vic. "Urban Probiems and the Legislature." Greater Portland Commerce. Vol. 55, \#6, Feb., 1971, pp. 12-15.

Long, Norton E. The Polity. Chicago: Rand McNally and Co., 1962 .

Lybrand, Ross Brothers, and Montgomery. Program for Combining EDP Systems. Portland, Oregon: Lybrand, Ross Brothers, and Montgomery, Mar. 26, 1955.

MacDonald, Austin F. American City Government and Administration. New York: Thomas Y. Crowell Company, 1956.

Maddox, Russell W. Issues in State and Local Government: Selected Readings. Princeton, N. J.: D. Van Nostrand, 1965 .

-...., and Fuquay, Robert F. State and Local Government. Princeton, N. J.: D. Van Nostraña, 1962 . 
Makielski, S. J. Jr. "CitymCounty Consoliaation in the U. S." University of Virginia News Letter, Charlottesville, Virginia: University of Virginia, Oct. 15, 1969.

Mariner, Elwyn E. This is Your Massachusetts Government. Arlingtion Heights, Massachusetts: Mariner Books, Mar., 1970 .

Nartin, Richard. Consolidation: Jacksonville-Duval County; The Dynamics of Jrban Political Reform. Jacksonville, FIorida: Convention Press, 1968 .

----, A Sumrary of Consolidation: Jacksonvilie-Duval County; The Dynamics of Urban Political Reform. Jacksonvilie, Florida: Convention Press, 1968.

Massachusetts, State of. News Release \#JY-45. Boston: Governor's Press Office, July 10, 1970.

-.-., News Release \#JY-95. Boston: Governor's Press Office, July 23, 1970 .

----, New Release \#JE-31. Boston: Governor's Press Office, Jan. 10, 1971.

- - House No. 5453: Legislative Research Council: Report Relative to Voluntary Municipa I Merger Procedures. Boston: Wright ard Potter Printing Company, 1970.

, House No. 4988: Legislative Research Council: Report Relative to Regional Government. Boston: Wright and Potter Printing Company, 1970 .

-.-- House No. 6125: Report of the Special Commission Relative to the Modernization of County Government. Boston: Wright and Potter Printing Company, 1970.

Matthew, John. "Minority Rights." - Letter to the Editor. The Oregonian. May 30, 1971.

"Mayor Shifts Cjty Duties." The Oregonian. Dec. 25, 1970.

Mauảin, Gene. "RegionaI Planning Meeting Slated for January 5." Eugene Register Guard. Dec. 25, 1970.

Mayo, Fesler. "Denver Consolidation - A Shining Light." National Municipa]. Review. No. 29, June 1940, p. 380.

McCall, Tom. "Future Bright for Consolidated Port Agency." The Oregonian. Nov. 5, 1970 . 
McCready, Connie and Baker, Doug. "How and When Divide Two Candidates on City-County Consolidation." The Oregonian. Oct. 1, 1970 .

McDill, E. L. and Ridley, J. C. "Status, Anomia, Political Alienation, and Political Participation." American Journal of Sociology. Sep., 1962, pp. 205-213.

McKean, Doug. "City-County Merger Debated." Oregon Journal. Mar. 10, 1971.

----, "Nierger Foes Plan Referral." Oregon Journal. June 14,1971 .

---, "Session May End Tuesday." Oregon Journal. June 2, 1971 .

----, "Senate Unit Votes to 'Merge' Port." Oregon Journal. May 21, 1971.

--.--, "Merger Bill OKd in Senate." The Oregon Journal. May 29, 1971.

McNeely, Patricia G. "Road Council Started Government." Columbia Record. Feb. 6, 1971.

----, "Expansion Laws Seen as 'Laughing Matter'." Columbia Record. Feb. 8, 1971.

-..--, "Ten Tax Districts Like 'Puzzle'." Columbia Record. Feb. 9, 1971.

-..-. "'Merger' Given Units' Blessings." Columbia Record. Feb. 10, 1971 .

--.--, "Police Merger Issue Draws Varied Views." Columbia Recora. Feb. 11, 1971.

----, "Thoughts Varied on Merger Issue." Columbia Record. Feb. 12, 1971 .

"Merger Bill A Must." The Oregonian. Apr. 5, 1971.

"Merger Bill Sent Panel." The Oregonian. Apr. 29, 1971.

"Merger?" The Press N.W. May 12, 1971.

"Merger Bill Sent to McCall." Oregon Journal. June 8, 1971.

"Merger Changes Opposed." Oregon Journal. May 21, 197.1. 
"Werger Cut Tax Bill." The Oregonian. Dec. 17, 1970.

"Merger Foe Hints At Move." The Oregonian. May 26, 1971.

"Merger Has Enemies." The Oregonian. May 22, 1971.

"Merger in Salem." The Oregonian. Aug. 21, 1971.

"Merger Moves Ahead." The Oregonian. Nov. 5, 1970.

"Merger of Courts Held Up." Oregon Journal. Sep. 9, 1971.

"Merger Project Advances." Oregon Journal. Sep. 10, 1971.

"Merger Proposals Aired at Meeting." The Oregonian. Mar. $19,1971$.

Mershon, Andrew. "Foes of City-County Merger Fire Best Shots at Committee." The Oregonian. May 14, 1971.

----., "Legislators Push for Inclusion of Port of Portland in City-County Consolidation." The Oregonian. May 6, 1971 .

----, "Super-City Plan Spices Merger Controversy." The oregonian. Mar. 11, 1971.

-.--, "East County Suburbanites BIast City-County Consolidation Measure." The Oregonian. Mar. 27, 1971.

----, "City-County Unification Decision Due." The Oregonian. Mar. 4, 1971.

-.-.., "City-County Werger Faces Tough Test in Salem." The Oregonian. Mar. 9, 1971.

Miller, James N. "Metro-Toronto's Answer to Urban Sprawl." Reader's Digest. August, 1967, pp. 85-89.

----, "A City Pulls Itself Together." The Reader's Digest. July, 1967, pp. 132-136.

"Missed Opportunity." The Oregonian. July 16, 1971.

Multnomah County, Oregon. Home Rule Charter, Multnomah County, Oregon. Portland: Count of Multroman, 1966.

NACO Round Table. "City-County Consolidations, Separations, and Federations." The American County. November, $1970, \mathrm{pp} .12-17,30-\overline{31}$. 
National Commission on Urban Problems. Hearings Before the National Commission on Urban Problems. Washington, D. C.: U. S. Government Printing Office, 1968.

Nelson, Howard J. A Case Study of Failure in Attempted Metro Integration: Nashvilie and Davidson County. Chicago: University of Chicago, $\overline{1961}$.

New Jersey, State of. Joint Services - A Local Response to Area-Wide Problems. Trenton, N. J.: County and Municipal Government Study Commission, Sep., 1970.

----, Creative Localism - A Prospectus. Trenton, N. J.: County and Municipal Government Study Commission, March 11, 1968.

----, County Government - Challenge and Change. Trenton, N. J. County and Municipal Government study Commission, N. D.

"New Mexico Cities Gain Home Rule." Western City. Jan. $1971, \mathrm{p} .12$.

North Dakota, Legislative Council of. State, Federal, and Local Government. Bismark, N. D.: State of North Dakota, 1970 .

Norton, James A. The Metro Experience. Cleveland, Ohio: The Press of Western Reserve University, 1963.

"November Referendum Tries Aimed at 3 More Measures." The Eugene Register-Guard. July 3, 1971.

Ohio Department of Urban Affairs. Councils of Government. Columbus, Ohio: State of Ohio, October, 1969.

"1.5 Million Dollars Sought for Joint Law Enforcement by City, County." The Oregonian. Apr. 23, 1971.

Onstine, Burton W. Unpublished Survey of Political Attitudes in Portland. Portiand, Fortland State University, 1970.

Oregon, State of. House Bill 1054. Salem, Oregon: Oregon State Legislative Assemb 1 y, 197.1.

-..-, Oregon Blue Book: 1971-1972. Salem, Oregon: State of oregon, 1971 .

Oregon Tax Supervision and Conservation Committee. Cost Comparison. Salem, Oregon: Oregon Tax Supervision and Conservation Committee. 1971. 
"Poit's a Pawn in 'Tricky Game." The Oregon Journal. May $22,1971$.

"Portland City Officials Lukewarm on Accomplishments of Oregon Legislature." The Oregonian. June 16, 1971.

Portland Metropolitan Study Commission. Interim Report: 1966. Portland, Oregon: Portland Metropolitan Study Commission, 1965.

-.--, "Regional Planning: An End of Too Little, Too Late." Portland, Cregon: Portland Metropolitan Study Commission, 1966. (mimeographed.)

; Report and Recommendations of the Portland Metropolitan Study Commission: 1969. Portiand, Oregon: Portland Metropolit an Study Commission, 1969.

, Report and Recommendations of the Portland Metropolitan Study Commission: 1971. Fortiand, Oregon: Portiand Metropolit ain Stuay Commission, 1971.

-.---, "The Consoliaation of Nashville and Davidson County." Portland, Oregon: Portland Metropolitan Study Commission, 1967. (mimeographed.)

----; "Paradise Lost?" PortIand, Oregon: Portland Metropolitan Study Commission, 1967. (mimeographed.)

-..--, "Bay Area Looks to Regional System." Portland, Oregon: Portland Netropolitan Study Commission, 1967. (mimeographed.)

----, "Minnesota Council Broadening Scope." Portland, Oregon: Portland Metropolitan Study Commission, 1968. (mimeographed.)

-..--, City-County Consolidation. Portland, Oregon: Portland Metropolitan Study Commission, 1969.

-..--, "The Twin Cities Metropolitan Council." Portland, Oregon: Portland Metropolitan Study Commission, 1969. (mimeographed.)

----, "Use of Community Councils in Washington." Fortland, Oregon: Portland Metropolitan Study Commission, 1969. (mimeographed.)

-----, "WiIl Consolidation Work? Reshaping Local Government." Portland, Oregon: Portland Metropolitan Study Commission, 1969. (mimeographed.) 
; "The Success of the Metropolitan Service District in Seattle:" Portland, Oregon: Fortland Metropolitan Study Commission, 1969. (mimeographed.)

----, "City-County Consolidation Proposal in Atlanta Area." Portland, Oregon: Portland Metropolitan Study Commission, Dec. 23, 1970. (mimeographed.)

----, "Constitutionality of 'Tax Differentials' as Provided for in HB 1054." Portland, Oregon: Portiand Metropolitan Study Commission, May 17, 1971. (mimeographed.)

"'Project 1980' Eaces Long, Uphili Battle." The Oregonian. January 10, 1971.

"Pros and Cons of Consolidation." The Press - City N.W. December 21, 1970.

"Regional Government is Needed - Now." Nation's Cities. Dec., 1969. p. 27.

Rehfuss, John A. "Metropolitan Government - Four Views." Urban Affairs Quarterly. Vol. III, \#4, June, 1968. pp. 91-11I.

Richarason, Richard J. Orleans Parish Offices: Notes on City-Parish Consolidation. New Orleans: Bureau of Governmental Research, 1961.

"Rising Taxes on Homes, and the Search for the Way Out." U. S. News and World Report. July 12, 1971. pp. 71-73.

"Rural Area Benefits by Merger." Oregon Journal. June 14, 1971 .

Rush, John A. The City-County Consolidated. Jos Angeles: By the Author, 1941 .

Rutledge, Hugh. "All Systems Still 'Go' for Unigov January 1." Press Release. Indianapolis, october 18, 1969.

--.--, "Making Unigov Work." - Series of five press releases. May 12, through May 19, 1969.

San Francisco, City and County of. City and County of San Francisco. San Prancisco: City and county of San Francisco, 1971.

-.- Appendix: San Francisco Commissions and Boards. San Prancisco: City ard County of San Francisco, N. D. 


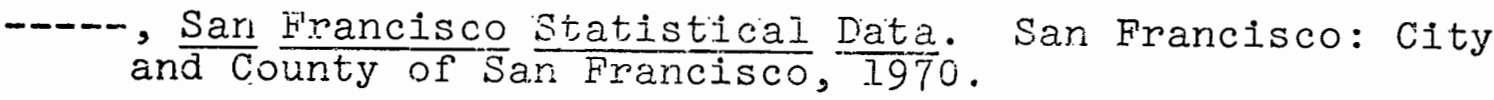

--.--, Information Sheet, San Francisco, California. San Francisco: City and count of San Frarcisco, 1970.

-.---, The Consolidated City and County Governmient of San Francisco. San Francisco: City and County of San Francisco, 1966.

, Board of Supervisors: City and County of San Francisco. San Francisco: City and County of San Francisco, 1970.

, Board of Supervisors: City and County of San Francisco: A Narrative Description. San Francisco: City and County of San Francisco, 1960 .

-..- , Summary of the Charter of the City and County of San Francisco. San Francisco: City and County of San Francisco, N. D.

Sanderson, William. Editorial Cartoon - "The Acid Test." The Press N. W. June 2, 1971.

Sayre, Wallace S. and Kaufman, H. Governing New York City. New York: Russell Sage Foundation, 1961.

Schmandt, Henry J., Steinbicker, Paul G. and Wendell, George D. Metropolitan Reform in St. Louis: A Case Study. New York: Holt, Rinehart, and winston, 1961 .

Schmandt, Henry J. and Standing, William H. The Milwaukee Metropolitan stuay Commission. Bloomington: Indiara University Press, 1965.

Schrunk, Terry. The Mayor's Annual Message to the City Council. Portland: Department of Finance and Administration, 1966.

-.--, "Council Discusses Unity Plan." The Oregonian. May $15,1968$.

"Schrunk Suggests Priorities." Oregon Journal. July 27, 1971 .

Schultz, Blaine. "Few Changes in Staff Expected in PortDock Facilities Merger." The Oregonian. Nov. 13, 1970.

Scott, Thomas M. "Metropolitan Governmental Recrganization Proposals:" The Western Political Quarterly. Vol. XXI, \#2, June, 1968, pp. 252-261. 
Seago, Les. "Beaten in County." The Chattanooga Times. Aug. 7, 1970 .

Seidl, Arline. "Kill the Bill \#1054 - City-County Consolidation." Flier, Mar. 25, 197I. (mimeographed.)

Select Committee on Consolidation: Senate Local Government Committee. Minutes of Public Meeting. Salem, Oregon: Oregon State Senate, May 13, 1971. (mimeographed.)

--.--, Minutes of Public Meeting. Salem, Oregon: Oregon State Senate, May 5, 1971. (mimeographed.)

Sellers, Jim. "Legal Aspects of Merging Public, School Bus Systems Under Study." Eugene Register-Guard. Mar. 28, 1971 .

Sengstock, Frank S., et al. Consolidation: Building A Bridge Between City and Suburb. Worchester: Hefferman Press, 1964 .

"Several Sides to Urban Issue." Oregon Journal. May 6, 1971.

Seymour, Douglas. "Measure Proposes Procedures for CityCounty Consolidation." The Oregonian. Jan. 21, 1971.

-.- "Merger of City, County Gains." The Oregonian. Apr. 28, 1971 .

Seplow, Stephen. "City, County Merger for Indianapolis." The Des Moines Register. Jan. 18, 1970.

Simon, Herbert A. Fiscal Aspects of Urban Consolidation. Berkley: University of California, 1943.

Smallwood, Frank. "Modernizing Local Government: A Second Look." iNation's Cities. Vo1. 5, \#3, March, 1967, pp. $21-33$.

Smith, Alfred F. "San Francisco: Consolidation Pioneer." National Municipal Review. No. 30, Mar., 1941, p. 152.

Sofen, Edward. The Miami Metropolitan Experiment. New York; Doubleday-Anchor, $196 \overline{6}$.

"Something New Under the Georgia Sun." Georgia County Government Magazine. August $1970, \mathrm{pp} \cdot 22-42$.

South Dakota, State of. South Dakota Planning and Development Districts. Sioux Falis, S. D.: State of South Dakota, N. D. 
-.--, Revised Planning Legislation Fouse Bill 846. Sioux Falis, S. D.: State of Scuth Dakota, Feb. I7, 1970.

Spence, Martin. "Vote Could Delay Cjty-County Merger." Oregor Journal. June 19, 1971.

Stephan, Frederick F. and McCarthy, Philip J. Sampling Opinions. New York: Johr Wiley and Sons, 1958.

"State Readies for Petition Flood." The Oregonian. Sept. 8, 1971 .

"State Studies Petitions Aimed at Cigarette, Auto Taxes, County Consolidation." The Oregoniar. Sept. 10, 1971.

"Steps in City-County Merger." Oregon Journal. Apr. I5, 1971 .

Stuaxt, Mrs. Sed. "All Will Get Vote." - Letter to the Editor. The Oregonian. Mar. 20, 1971.

"Successor of City and County." Oregen Journal. Sep. 15, 1971 .

"Taming Metropolitan Growth." Nation's Cities. Jan., 1968, p. 16 .

Taxpayers for Consolidated Government. Series of Leaflets untitled. Chattanooga: Taxpayers for Consolidated Government, 1970. (mimeographed.)

-..--, Break the Chain of Waste and Duplication. Chattanooga: Taxpayers for Consolidated Government, 1970.

Temple, David Graham. The Tidewater Mergers: The Politics of City-County Consolidations in Virginia. Charlotte, Virginia: University of Virginia Master's Thesis, 1966.

"10 Super Cities - Home for I of Every 4 Americans." U.S. News and World Report. Aug. 2, 1971, p. 79.

Texas, state of. Texas Statutes: Article 3 Section 64. Austin, Texas: State of Texas, N. D.

--.-, 6lst Legislature, 1968, Chapter 28. Austin, Texas: State of Texas, N. D.

-.--, HJR 22. Austin, Texas: State of T'exas, Nov. 3, 1970.

-.--, Texas Urban Community Development Fact Sheet. Austin, Texas: State of Texas, N. D. 
"Three Mayors Review Their Governments." Nation's Cities. Nov. 1969, p. 26.

"Three-Phase Program Aims at Creation of Combined Spokane City-County Government." The Oregonian. Dec. 5, 1970.

"Trap for Consolidation Bill." Oregon Journal. May 20, 1971.

"mroutdale Annexation Approved." Oregon Journal. Sept. 10, 1971 .

"Twin Cities Area Council is Created." National Civic Review. Vol. LVI, \#7, July, 1967. pp. 410-411.

"Two Legislators Fight Wording of City-County Consolidation, Cigarette Tax Measures." The Oregonian. July 15, 1971 .

"Two Men - One Vote." Oregon Journal. June 19, 1971.

UhIman, Wes. "Seattle's Mayor Tackles the City-County Consolidation Bogeyman." The Oregonian. Dec. 13, 1970.

UNESCO. Handbook for Social Research in Urban Areas. Paris: U. N. Publishing, 1964 .

Urban Action Clearinghouse. Jacksonville, Florida Merges City and County Governments: Case Study \#4. Washington D. C.: Chamber of Commerce of the U. S., 1.968.

Urban Studies Center, Portland State University. Annexation, Incorporation and Consolidation in the Portland Netropolitan Area. Portland: Portland state University, 1968 .

"Urigov." HUD Challenge Magazine. May, 1971, pp. 4-8.

"Unit Created to Draft Pact for City-County Merger." The oregonian. Sep. 10, 1971 .

Vance, Rupert B. and Smith, Sara. Metropolitan Dominance and Integration in Cities in Society. New York: The Free Press, 1957 .

Vernon, Eugene J. "Portland County?" - Letter to the Editor. The Oregonian. Mar. 20, 1971.

Virginia Metropolitan Areas Study Commission. Governing the Virginia Metropolitan Areas: An Assessment. Richmond, Virginia: Commonwealth of Virginia, 1967 . 
Virginia, State of. Code of Virginia, Chapter 26, Article 4, Section 15. Richmond, Virginia: state of Virginia, N.

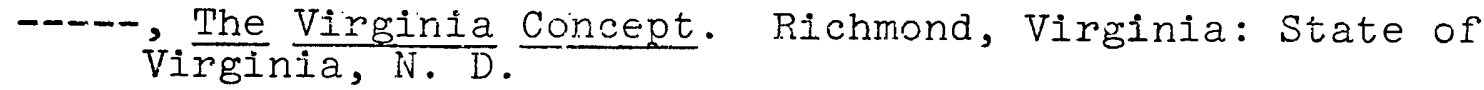

"Vote Sought on 2 More Statutes." The Oregonian. July 3 , 1971 .

"Walsh Versus Ivancie." The Portland State University Vanguard. October 30, $\overline{1970}$.

Warren, Robert. "A Municipal Services Market Model of Metropolitan Organization." Journal of American Institute of planners, Vol. XXX, \#3, August, $\frac{1964, \mathrm{pp}}{\frac{193-204}{193-}}$

Warren, Robert. "Political Form and Metropolitan Reform." Public Administration Review. Vol. XXXIV, \#3, Sep. 1964, pp. 180-187.

Washington, State of. State Constitution, Amendment 23 . olympia, Washington: State of wiashington, Novemb er, 1948.

"Washington Cities Gain at State Legislative Session." western City. July, 1969, p. 32 .

Watson, Richard A. and Romani, John H. "Metropolitan Government for Metropolitan Cleveland: An Analysis of the Voting Record." Midwest Journal of Political Science. Vol. V, \#4, Nov., 1961, pp. 365-390.

Webb, Robert. "Merger Indy's 'Miracle'." The Cincinnati Enquirer. June 1, 1969.

White, A. G. Portland-Multnomah County Consolidatjon Chances fOr Success. Portland, unpublished paper, June 5,1970 .

----, Regional Flanning in City-County Consolidated Governments. Portland, unpublished paper, March 15, 1971.

Wickenberg, Charles. "Two South Carolinian Areas in Consclidation Effort." The Columbia, S.C. State. Feb.2, 1971.

---, Urban Problems Spili Over Boundaries." The Columbia, S. C. State. Feb. 1, 1971.

-...-, "Consolidation Effort Now Taking on Some Substance." The Columbia, S.C. State. Jan. 31, 1971. 
-.-., "Urban Problems Spill Over Boundaries." The Columbia, S. C. State. February 1, 1971.

---, "Consolidation Effort Now Taking on Some Substance." The Columbia, S. C. State. January 31, 1971.

Winchester, City of. Annexation Information. Winchester, Virginia: City of Winchester, 1970.

Wisconsin, State of. Alternative Approaches to Metropolitan Problems. Madison, Wisconsin: State of Wisconsin, N. D.

Wolf, Peter. "Consolidation: Getting It All Together." The Press - City N.W. October 7, 1970.

Women Voters, League of. November 3 , 1970 General Elections: Vote. Portlana: Vol. XIV, \#2, N.

-...., May 26, 1970 Primary Election: Vote. Portland: Vol. $\mathrm{XIV}, \# \bar{I}, \mathrm{~N} . \overline{\mathrm{D}}$.

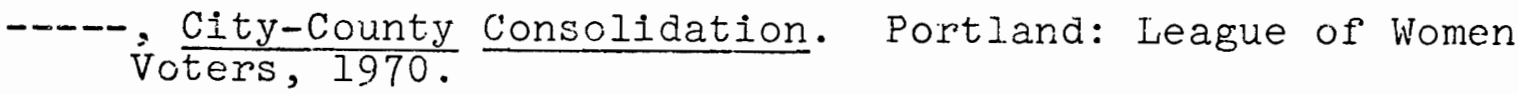

Yocom, Doug. "East County Residents Continue Merger Fight." Oregon Journal. May 14, 1971.

----, "City, County Mereer Plan Passed by House." Oregon Journa1. Apr. 27, 1971.

----, "Merger Move Nets Protest." Oregon Journal. Mar. 26, 1971 .

Zimmernan, Joseph F. Metropolitan Crarters. Albany, N. Y.: State University of IJ. Y., 1967.

-..-, "Political Alienation and the Electoral System." Speech before the National. Conference on Government, Portland, Oregon, Aug. 20, 1970.

\section{STATISTICAL DATA SOURCES}

Bureau of the Census. County and City Data Book 1967 - A Statistical Abstract Supplement. Washington, D. C.: U. S. Government Printing Office, 1967 .

----, Census of the United States: 1940; 1950; 1960; 1970. Washington, D. C.: U. S. Government printing Dffice, 1941; 1951; 1961; 1971 (Preliminary). 
-.---, 1967 Census of Governments: Governmental Organization. Washington, D. C.: U. S. Government Printing Office, 1967.

Information Please Alrianac, Atlas, and Yearbook. Editions 1965, 1970, 1971. New York: Simon and Schuster, 1964; $1969 ; 1970$. 


\section{APPENDIX I \\ GLOSSARY OF TERMS}

TERM

City-County Separation

\section{DEFINITTON}

The withdrawl of a municipal corporation from the county surrounding it. The municipality in effect becomes its own county. The former county looses all jurisdiction within the city limits - the regional boundaries are the city limits.

EXAMPLE: St. Louis, Missouri (1876); the "independent cities" of Virginia, circa 1870.

Consolidation The complete aissolution of two or more governmental urits to form a new, distinct governmental unit with jurisdiction over the former territory, and with responsibility for performing the former functions, of the dissolved units.

A. City-city The consolidation of two or more cities to form a single municipal corporation. EXAMPIE: Oceanlake-Taft-Delake into Lincoln City, Oregon (1964).

B. Citycounty
The consolidation of a county with some or all of the municipalities within it. 
EXAMPLE: Nashville-Davidson County, Tennessee (1962)。

C. Functional The consolidation of departments or service units between governmental bodies without the surrender of separate identities on the part of either governing body.

EXAMPLE: Seattle-King County, Washington's City-County Health Department.

D. Partial The consolidation of part of one governmental unit with another whole or partial unit, or city-city or city-county consolidation which retains several major functions or some territory under portions of one of the former municipalities or the county. EXAMPLES: Boston-Suffolk County, Massachusetts (1821); San Francisco-San Francisco County, California (1856).

Council of Government ( $\underline{\mathrm{COG}}$
"A multijurisdictional organization which involves more than one local government and encompasses a portion of a state or portions of contiguous states. It's prime purpose is increasing cooperation among 1ocal governments in meeting mutual challenges and problems in the area." - Massachusetts Legislat1ve Research Council, Report Relative to Regional Governmert (Boston, Wright and 
Extrater-

ritorial Powers

Federation

IntergovernmentaI Cooperation
Potter Printing Co., 1970), pp. 44-45. EXAMPLE: Portland, Oregon's four-county Columbia Region of Governments (CRAG). Those powers which a municipal corporation may exercise outside its corporate boundaries, as provided by regulation or by actual extension of a service function. EXAMPLE: Elkhorn and Walworth County, Wisconsin - city has control over zoning for five miles outside its houndary within the county. A two-tiered approach accomplished by establishing one level of government for the entire region and retaining the local municipalities to cope with local functions and to maintain visibility and accessibility. Very similar to the urban county approach. EXAMPLE: Metro Toronto, Canada.

A formal or informal cooperative agreement between two or more governmental units to aid one another, contract with one another, or transfer functions among one another to provide service on a regional basis.

A. Functional The transfer of responsibility for performTransfer

ance of some service from one municipal corporation to some other unit of government. EXAMPLE: Maintenance of urban ireeways/toll 
roads in New York City by the Port Authority of New York.

B. "Lakewood Performance of all major functions by a Plan" county for a muricipality by contract. EXAMPLE: Lakewood and Los Angeles County, California.

Merger

The absorption of one governmental unit by another, whereby the identity of the former is destroyed, and that of the latter is potentially strengthered politicaliy and economically through the broadening of its economic and political bases. EXAMPLE: The merger of Jauralhurst and Portland, Oregon.

Service

Districts

A. Special A limited-purpose, independent unit of government organized, usually by state law and without popular consent, to perform one (or a very few) function(s) throughout a portion of a metropolitan region. EXAMPLE: Metropolitan Sewer District (partial) of Boston, Massachusetts.

B. Metropol- A special authority established to perform a itan number of services throughout a metropolitan region. EXAMPLE: Metropolitan Service District of 
Portland, Oregon.

Urban County The strengthening of the county as a regional government, so that it provides urban-type services throughout the county in the same manner that a municipality might. Political subdivisions of the county retain their identities, but many services may be surrendered to the county by them. The county may set some county-wide standards as it sees fit, such as building, plumbing, and electrical codes. EXAMPLE: Metropolitan Dade County (Miami), Florida. 


\section{APPENDIX II}

\section{TEST INSTRUMENTS}

Reproduced on the following pages are the questionnaires used in the survey portion of this study. The state questionnaire is on page 113; the questionnaire to the consolidated cities is on page 114; the questionnaire to the control group is on page 115; and the questionnaire to the group of consolidation failures is on page 116.

Each questionnaire was directed to either the mayor's office or an office or individual identified in the ifterature (or in a previous portion of the survey process) as a focal point in reorganization efforts. 
STATE

DATE INDIVIDEAL RESPONDING TITTE OF INDIVIDUAL

i. Does your state have any city-county consolidated/merged units?

IF YES: A. Are they functional (service/departmental) or formal (governmental)

B. What is the major city involved? What is the county involved?

2. Is state legislation required in your state for citycounty consolidation?

IF YES: What is the major statute?

YES

3. Do any cities in your state have firm plans or commitnents for city-county consolidation?

NO

IES

IF YES: Major City? (1) County?

(1)

(2)

4. Does your state officially favor such consolidations?

NO

YES

5. Any adoitional comments on local government consolidation reorganization? 
CITY

DATE

INDIVIDUAL RESFONDING

IITTE OF INDIVIDUAL

YEAR OF CONSOLIDATION

1970 POPULATION

1970 LAND AREA

1970 ASSESSED VALUE.

Is your consolidation FUNCTIONAL (service/departmental) or FORMAL (governmental). ?

1. What were your reasons for consolidating?

2. Are you legally considered (A) a city _ or (B) an urban county ?

3. Have problems of a social nature (welfare, race, etc.) arisen since or as a result of your consolidation? No YES

IF YES: Please describe: 4. Have you had to ( $A$ ) raise taxes (NO YES ) or (B)
institute service charges (NO_ NES_ institute service charges (NO YÉS consolidating?

IF YES: Please describe how much or on which services:

5. Do you feel that you have been able to plan more effectively since consolidating?

How so or why not?

NO

YES

6. What advice would you give to other city/county governments concerning consolidation? 
CITY

DATE

INDIVIDUAL RESPONDING TITIE OF INDIVIDUAL

1970: POPULATION AREA ASSESSSED VALUE

i. Has your city's governmental structure or scope ever been Ereatly altered ("reformed") since it was incorporated?

NO

YES

IF YES: A. What form did the alteration take (mayor-to manager; consolidation; reorganization of departments, etc.)?

B. When did it take place?

C. Have social problems (welfare, race, etc.) arisen since or as a result of that last alteration?

IF YES: Please describe:

YES

D. Have you had to $(A)$ raise taxes (NO or (B) institute service charges since that last alteration?

IF YES: Please describe how much or on with services:

E. Do you feel that you have been able to plan more effectively since that last alteration?

NO

How so or why not?

YES

F. What advice would you give to other cities about this form of reorganization?

2. Are "good government" or other groups contemplating or lobbying for changes in your city's government structure?

IF YES: What kind of changes? NO

YES

When would these changes become effective?

3. Any comments on governmert reorganization in cities in the United States? 
CITY

DATE INDIVIDUAL RESPONDING TITSE OF INDIVIDUAL

DATE CONSOLIDATICN DEFEATED

$\begin{array}{ll}\text { MARGIN OF DEFEAT: } & \text { CITY (FOR) TO (AGAINST) } \\ \text { COUNTY (FOR)—TO (AGAINST) }\end{array}$

1. What is your estimate of the cause(s) of failure to consolidate?

2. What kinds of groups arose in opposition to the consolidation?

3. What kind of education program was performed to aquaint the voters with the consolidation issue?

4. What was most objected to?

Big Government Higher taxes Consolidation concept

Loss of local governmental jobs

Reduction of local participation

Other:

5. Have other types of reorganization taken place in your city since the consolidation defeat?

6. Are there or have there been any attempts to resubmit the consolidation proposal to the voters? 


\section{APPENDIX III}

\section{RESULTS OF STATE SURVHY \\ QUESTIONS $1-3$}

1. Consolidated units in your state?

YES (Functional and FormaI):

$\begin{array}{lll}\text { Alaska } & \text { Indiana } & \text { Pennsylvania } \\ \text { Colorado } & \text { Louisiana } & \text { Ternessee } \\ \text { Florida } & \text { Massachusetts } & \text { Virginia } \\ \text { Georgia } & \text { Nevada } & \\ \text { Hawaii } & \text { New York } & \end{array}$

YES (Functional Only):

Arkansas Nebraska Utah

Idaho South Dakota

2. Legislation required in your state for consolidation?

YES (Constitution plus Amendments):

$\begin{array}{lll}\text { Arkansas } & \text { Hawaji } & \text { Pennsylvania } \\ \text { Colorado } & \text { New York } & \text { Virginia } \\ \text { Georgia } & \text { Oregon } & \text { Washington }\end{array}$

YES (House, Senate, Joint Bills):

$\begin{array}{lll}\text { Alaska } & \text { Michigan } & \text { Tennessee } \\ \text { Florida } & \text { Nebraska } & \text { Texas } \\ \text { Kentucky } & \text { Nevada } & \text { Vermont } \\ \text { Louisiana } & \text { South Dakota } & \end{array}$

YES (None Available or No Response):
Alabama
Arizona
Delaware
Kansas
New Hampshire
Idaho
Massachusetts
Minnesota
New Jersey
Indi.ana
Missour1
Montana
North Carolina
South Carolina
wyoming 
3. Actions currently under way to create consolidated units? YES: Alaska North Carolina South Dakota Georgia South Carolina Virginia 


\section{APPENDIX. IV}

RESULTS OF CONSOIIDATED GROUP SURVEY

1. Major reasons for consolidating? See text.

2. Consolidated unit legally a city? YES for all 17.

3. Social problems arisen?

YES: 0 NO: 16 NO RESPONSE: New Orleans

4. Had to raise taxes?

YES : Nantucket New Orleans

Nashville New York

Chesapeake Virginia Beach

Hampton

Denver

Honolulu
NO: Carson City

Columbus

Juneau

Indianapolis

Baton Rouge

Jacksonvilite

Had to institute service charges?

$\begin{array}{lcl}\text { YES: Denver } & \text { NO: Carson City } & \text { Nashville } \\ \text { New York } & \text { Nantucket } & \text { Newport News } \\ \text { New Orieans } & \text { Columbus } & \text { Chesapeake } \\ \text { Jacksonville } & \text { Juneau } & \text { Baton Rovge } \\ \text { Indianapolis } & \text { Hampton } & \\ \text { Virginia Beach } & \text { HoncluIu } & \end{array}$

NO RESPONSE: Philadelphia

5. Been able to plan more effectively?

$\begin{array}{lll}\text { YES: Denver } & \text { Carson City } & \text { NO: Baton Rouge } \\ \text { Hampton } & \text { Virginia Beach } & \\ \text { Juneau } & \text { Newport News } \\ \text { Coiumbus } & \text { Indianapolis } \\ \text { Honolulu } & \text { Jacisonville } \\ \text { Nashville } & \text { Philadelphia }\end{array}$

NO RESPONSE: Nantucket New Orleans Chesapeake New York 
6. Advice to other governments on consolidation?

"(Consolidated government) is more economical because it eliminates duplication of government and services." Honolulu.

"In some cases, city-county consoliaation may be the answer to nany problerns." - Philadelphia.

"This system has worked very well for Denver." - Denver.

"Efforts to consolidate must take cognizance of political as well as internal governmental factors and problems." Indianapolis.

"A great deal to offer, but not necessarily to all." Carson City.

"For those contemplating it: be bol.d and do it." - Juneau. "Proceed!" - Baton Rouge. 


\section{APPENDIX V}

RESULTS OF CONTROL GROUP SURVEY

1. Governmental structure ever been greatiy altered? YES : 13 NO: Lexington Hot Springs

Atlanta Tampa

(Question 2): Contemplating changes?

YES: Tampa - consolidation with Hillsborough Co.

NO: Isexington

Atlanta

Hot Springs

IF YES: A. What form has the alteration taken? $(N=13)$

Mayor to manager: Des Moines Huntjngton Greenville

Dallas

Cleveland (back to mayor)

Weak manager/strong mayor to strong manager/ weak nayor: Phoenix

Weak mayor to strong mayor: East Hartforã

Commission to mayor-council: Birmingham Memphis

Mayor-alderman to commission: Lafayette

Ward system to council-at-large: Detroit

Charter revision, strengthened nanager:

\section{San Jose}

Consolidation with another city: Union City

B. Social problems arisen?

YES: Phoenix Dallas

Memphis Cleveland

Detroit Huntington 

(1.)
(B.) NO: East Hartford
San Jose
Birmingham
I afayette
Greenville
Union City
Des Moines

C. Had to raise taxes?

YES: Huntington

Birmingham

Greenville

Irafagette
Phoenix
Memphis
Detroit

Dallas

Cleveland

Union City

San Jose

East Hartford

NO: 0

NO RESPONSE: Des Moines

Had to institute service charges?
YES: Greenville Lafayette NO: Dallas Huntington Memphis Phoenix Union City Cleveland Birmingham Des Moines San Jose

NO RESPONSE: Detroit East Hartfora

D. Been able to plan more effectively?

YES: Birmingham Dalzas

Greenville Memphis

Huntingtion Phoenix

Des Moines East Hartford

Laf'ayette

NO: Union City NO RESPONSE: Cleveland San Jose Detroit

E. Advice to other governments on this form of reorganization?

WOUID RECOMMEND: Greenville Des Moines

Huntington East Hartford

Birmingham

RECOMMEND AGAINST: San Jose Union City

Lafayette Phoenix

Cleveland

NO RESPONSE: Dallas

Detroit

Memphis 
2. Cortemplating charges?

YES: Cleveland - urban county

Des Moines - to commission structure

Union City - service/departmental consolidation

Birmingham - city-county consolidation

Memphis - city-county consolidation

Lafayette - cominission to strong mayor

Greenville - regjonal government

Detroit - charter revision

San Jose - charter revision

Dallas - yes, but no response as to type

NO: East Hartford

Phoenix

Huntington

3. Any recommendations/comments?

"Change for change's sake alone is not good practice." Dallas

"Need reversal in trend of tax dollars going to the federal government." - Huntington

"Local governments must gravitate towards metropolitan and area-wide approaches to solving mutual problems." Last Hartford

"Consolidation would help lower the costs of providing services." - Union Ci.ty

"Some cities have apparently failed to prevent physical and social decay under the present system of regulations and controls - they may have to surrender home rule for more control from the federal government." - Cleveland 


\section{APPENDIX VI}

\section{BACKGROUND MATHEMATICS}

This appendix lists, in simple mathematical terms, several definitions which are necessary for a fuller understandjng of the terminology used in the section on mathematical models. More rigorous definitions can be found (if references are not given) in most standard freshman and sophomore mathematics texts.

Definition 1: Variable - a symbol which can take on varying values, numerical or otherwise.

Definition 2: Dependent variable - a variable that depends on the value of another variable for its value.

Definition 3: Independent variable - a vaxiable which does not depend on another variable for it: value.

Definition 4: Function - a relationship between a dependent variable and one or more independent variables such that, as the independent variable(s) take(s) on different values $\left(x_{i} \neq x_{j}\right.$ if $i \neq j$ ), then there is one and only one value of the dependent variable determired. The notation is

$$
y=f(x)
$$

read as " $y$ equals a function of $x$ ". Here $y$ is the dependent variable and $\mathrm{x}$ is the indepencent variabie. Some examples of functions are: 


$$
\text { (a) } \begin{aligned}
y & =f(x)=3 x-7 \\
\text { (b) } z & =f(x, y)=x^{2}-2 x y+3 \\
\text { (c) } R & =f\left(x_{1}, x_{2}, \cdot x_{3}+, x_{n}\right) \cdot-9 x_{n}^{3} \\
& =3 x_{1}+x_{2}
\end{aligned}
$$

In example (a), there is one independert riable, $x$. In example ( $b$ ), both $x$ and $y$ are independent variables. In example (c), there are $\mathrm{n}$ independent variables which determine the value of the dependent variable, $R$. Definition 5: Curve - if it is agreed that a "flat" surface is a plane, then a curve is the intersection (passing through of) any surface with a plane. Examples: a Iine is the intersection of two planes; a parabola is the intersection of a plane and a portion of a cone; a circle is the intersection of a plane with another portion of $a$ cune (a cross-section).

Definition 6: Dimension - an extension into one direction of space. As represented in a function, the total number of dependent and independent variables. In definition 4, example (a) is two-dimensional; example (b) is three-dimensional; and example (c) is $n+1$-dimensional. Definition 7: Graph - a point-by-point description of a curve in space. In two-dimensional space, consider two lines intersecting in a point, at right angles to one another (for ease of computation). Isolate an arbitrary point from the intersection, and that point will be associated with the number 1 (and the point of intersection with 
the rumber 0). The segment of line from 0 to 1 is then the unit segment, and all other numbers of the real number system can be associated with points along both lines. By calling one line the $x$-axis, and the other the $y$-axis, then any point in this space can be described by an ordered pair $(x, y)$. Each point of a curve in this two-dimensional space is then described point-by-point in terms of $x$ and $y$, and a function devised to describe the relationship between the two. Thus these two lines marked off with the real numbers, and the collection of all the points $(x, y)$ associated with the points on the curve, are together called the graph of the curve. This process can be generalized to $\mathrm{n}$ dimensions, where each point is described by an n-tuple $\left(x_{1}, x_{2}, \ldots, x_{n}\right)$. Definition 8: Vector - a directed portion of a line, $\overrightarrow{A B}$, where the "magnitude" of $\overrightarrow{A B}$ is the length of the segment and the direction of $\overrightarrow{A B}$ is the direction from the base $A$ to the head $B$, with respect to some set of $x$ and $y$ axes. The notation for vectors from directed line segments is

$$
\overrightarrow{\mathrm{AB}}=\overrightarrow{\mathrm{v}}
$$

If the length of $\vec{v}$ is to be determined (as well as j.ts direction), then a coordinate system ( $\mathrm{x}$ and $\mathrm{y}$ axes) must exist in which the line of which $\overrightarrow{A B}$ is a segment of is a curve - its graph must exist. If the vector $\vec{\nabla}$ is thought of as having its base $A$ at the intersection of the $x$ and $y$ axes, then the head $B$ can be described by the $n$-tuple of numbers fixing the point $B$ in space. 
Definition 9: Protection -. (see H.P. Manning's Geometry of Four Dimensions (New York, Dover Publications, 1914)) the construction of a perpendiculax (Iine at a right angie) from an $\mathrm{n}$-dimensional point $\mathrm{p}$ to a plane of $\mathrm{n}-1$ or fewer dimensions. The projection of a curve involves the projection of each point of the curve into such a plane. If $z=f(x, y)$ then the projection of the curve $z$ into tine $x-y$ plane is $\mathrm{y}=\mathrm{F}(\mathrm{x})$, where the function $\mathrm{f}$ is projected into the function $F$ coordinate-ky-coordinate.

Definition 10: World Iine - the set of all points which offer a description of a body or object in the universe of $\mathrm{n}$ dimensions through time. Heman Minkowski, a nineteenth century geometer, detemined the four-dimensional world line of physical objects to be a continuous curve in four-dimersional space (length, width, breadth, and time) consisting of the cocrinates that those objects had ever occupied (see Albert Einstein's Relativity: The Special and Ceneral Theories (New York, Crown Publishers, 1961), pp. 121ff. and Maurice Duquesne's Matter and Antimatter (New York, Collier Books, 1962), pp. 27fff.)。 